\title{
ARTICLES
}

\section{CONSTITUTIONAL TRADITIONALISM IN THE ROBERTS COURT}

\author{
Louis J. Virelli III $^{*}$
}

\begin{abstract}
The debate over the role of traditionalism in constitutional interpretation has itself become a tradition. It remains a popular and controversial topic among constitutional scholars and presents normative questions that are as divisive, difficult, and important today as at the Founding. Missing from the discussion, however, is a comprehensive account of how the Supreme Court has employed traditionalism - an approach that looks for meaning in present manifestations of longstanding practices or beliefs - in its constitutional jurisprudence. This project is the first to fill this gap by providing an exhaustive and systematic analysis of the Court's use of constitutional traditionalism. This article focuses on the Roberts Court's first five terms to provide an empirical foundation that will not only offer previously unavailable insights into the Court's current traditionalist practices, but
\end{abstract}

\footnotetext{
* Associate Professor of Law, Stetson University College of Law. I would like to thank Dean Erwin Chemerinsky for his early encouragement and advice on this project. I would also like to thank Mike Allen, Andrew Ferguson, James Fox, Joel Goldstein, Michael Heise, Meghan Irmler, Marco Jimenez, Orin Kerr, Bill Marshall, Andrew Martin, Ellen Podgor, and Lori Ringhand for their helpful comments and suggestions at various stages of the project. Versions of this paper were presented at the 2010 Constitutional Law Discussion Forum at the University of Louisville, Louis D. Brandeis School of Law, the 2009 Southeastern Association of Law Schools Annual Meeting, and a faculty workshop at Florida International School of Law, and benefitted immensely from the contributions of the participants at each event. Special thanks go to two generations of excellent research assistants-Chandler Irvin, Patrick McArdle, Meagan Martin, Krysta Matheis, Christa Queen-Sutherland, Aisha Sanchez, Robert Stines, and Traci Koster - and to the outstanding librarians and staff at the Dolly and Homer Hand Law Library at Stetson for their incalculable effort and assistance with this project. Any errors are entirely my own. This research was generously supported by a grant from Stetson University College of Law.
} 
U N I V E R S I T Y OF P I T T S B U R G H L A W R E V I E W

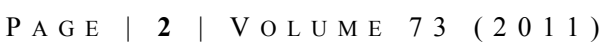

will also set forth a useful framework for the ongoing normative debate over traditionalism.

This project uses content analysis of key terms to identify every instance in which the Roberts Court employed traditionalism to interpret the Constitution. More specifically, this project set out to answer the following three questions: First, how frequently does the Roberts Court employ traditionalism in its constitutional jurisprudence? Second, how robust is the Court's use of traditionalism (i.e., is it used to interpret a broad or narrow range of constitutional provisions)? And finally, how often and in what contexts do individual Justices on the Roberts Court rely on traditionalism in their own constitutional opinions? The research provided here suggests answers to all three of these questions. First, the data indicate that traditionalism has been relied upon regularly by the Roberts Court, appearing in nearly half of the Court's constitutional cases. Second, traditionalism is frequently applied to a wide variety of constitutional provisions: Two-thirds of the constitutional provisions considered by the Roberts Court were subjected to a traditionalist analysis, ranging from provisions pertaining to government power and structure to individual rights. Finally, the data show that although traditionalism is used more frequently by conservative Justices, it is nevertheless employed by all members of the Court in a wide variety of contexts. Although there is more to learn about traditionalism's role in the Court's constitutional jurisprudence, this evidence makes clear that, notwithstanding the normative controversy surrounding traditionalism, any future study of the workings of this Court, its members, or of the future direction of constitutional law in general must take traditionalism into account. 
Table of Contents

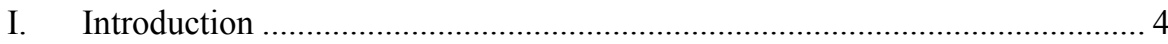

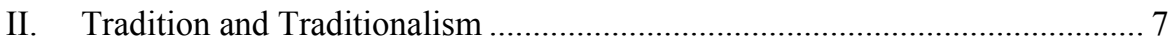

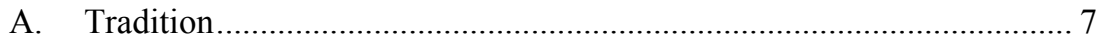

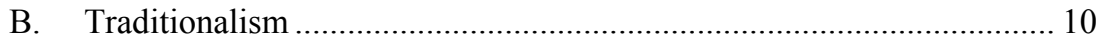

C. Modern Traditionalism Scholarship ..................................................... 17

III. Empirical Methodology ............................................................................... 20

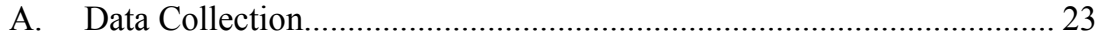

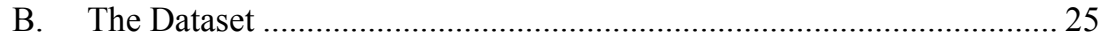

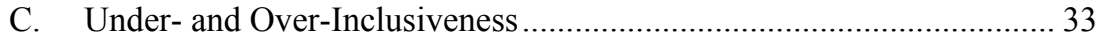

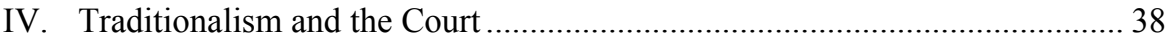

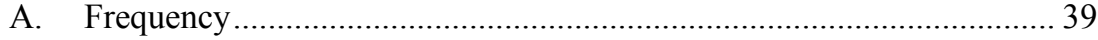

B. Breadth (Traditionalism by Constitutional Provision) …………............ 42

1. The Dormant Commerce Clause ……………............................... 43

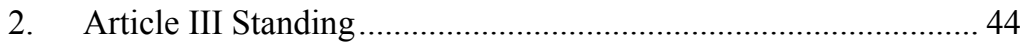

3. The Fourth Amendment................................................................. 46

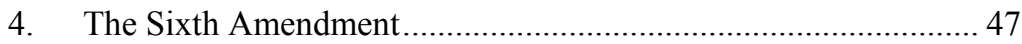

5. The Fourteenth Amendment ......................................................... 48

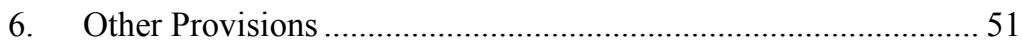

C. Identity (Traditionalism and the Justices) .............................................5

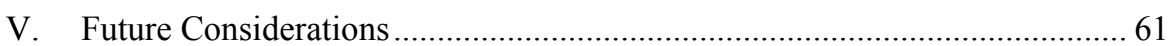

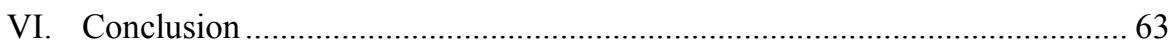


U N I V E R I T Y O F P I T T S B U R G H L A W R E V I E W

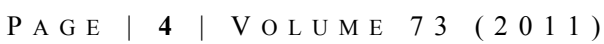

[N]o society can make a perpetual constitution, or even a perpetual law. The earth belongs always to the living generation. They may manage it then, and what proceeds from it, as they please, during their usufruct.

—Thomas Jefferson, Letter to James Madison, Sept. 6, 1789

[T]hat veneration which time bestows on every thing, and without which perhaps the wisest and freest governments would not possess the requisite stability... . The reason of man, like man himself, is timid and cautious when left alone ... [w] hen the examples which fortify opinion are ANCIENT as well as NUMEROUS, they are known to have a double effect. . . . [T] he most rational government will not find it a superfluous advantage to have the prejudices of the community on its side.

—James Madison, The FedERALIST No. 49

\section{INTRODUCTION}

The debate over the role of tradition in American constitutional law is older than the Constitution itself. Thomas Jefferson was highly critical of backwardlooking searches for constitutional meaning, arguing that "the earth belongs in usufruct to the living ... the dead have neither powers nor rights over it." James Madison, by contrast, echoed the philosophy of Edmund Burke in valuing the collective wisdom of the past for constitutional interpretation. ${ }^{2}$ From its origins at the highest level of American legal and political discourse, the debate over the role of traditionalism - the process of looking for meaning in present manifestations of longstanding practices or beliefs ${ }^{3}$ - in constitutional interpretation has itself become a tradition, remaining a popular and controversial topic among constitutional scholars, historians, and political scientists. ${ }^{4}$ Despite their age and

\footnotetext{
${ }^{1}$ Letter from Thomas Jefferson to James Madison (Sept. 6, 1789), in 12 THE PAPERS OF JAMES MADISON 382 (Charles F. Hobson et al. eds., 1979).

2 See Richard Beeman, Plain Honest Men: The Making of the American Constitution 421 (2009) (describing Madison's constitutional view as being "profoundly respectful of history and of tradition").

${ }^{3}$ For a more thorough discussion of the definitions of "tradition" and "traditionalism," see infra Part II.

4 See, e.g., Alexander Bickel, The Least Dangerous Branch (1961); Edmund Burke, REFLECTIONS ON THE REVOLUTION IN FRANCE (1791), reprinted in 2 THE GREAT POLITICAL THEORIES 53 (Michael Curtis ed., 1981); John Hart Ely, Democracy and Distrust (1980); Charles A. Miller, The Supreme Court and the Uses of History (1969); Michael J. Perry, The CONSTitution, THE COURTS, AND Human Rights (1982); CASS R. Sunstein, A CONSTITUTION OF
} 
pedigree, however, the normative questions surrounding constitutional traditionalism are as divisive, difficult, and relevant today as they were at the Founding.

Current trends in constitutional scholarship reflect the importance of traditionalism to modern constitutional theory. In the past five years, prominent commentators such as William Eskridge, David Strauss, Cass Sunstein, and Adrian Vermeule have published numerous books and articles dealing directly with constitutional traditionalism. ${ }^{5}$ Missing from the discussion, however, is any comprehensive or cohesive account of how (if at all) the judiciary - and especially the Supreme Court-has employed traditionalism in its constitutional jurisprudence; references to the Court's reliance on traditionalism have thus far been almost entirely anecdotal. This project is the first to fill this gap. It uses content analysis of key terms to provide an exhaustive, systematic analysis of the way in which the Supreme Court has used traditionalist reasoning in its constitutional decisions. This article focuses on the Roberts Court's first five terms in order to supply an empirical foundation that will not only offer heretofore unavailable insight into the Court's most current traditionalist practices, but will also provide a useful framework for the ongoing normative debate over traditionalism. ${ }^{6}$

MANY Minds (2009) [hereinafter SunsteIn, MANY Minds]; Rebecca L. Brown, Tradition and Insight, 103 YALE L.J. 177 (1993); Anthony T. Kronman, Precedent and Tradition, 99 YALE L.J. 1029 (1990); Lawrence Lessig, Fidelity in Translation, 71 TeX. L. ReV. 1165 (1993); David J. Luban, Legal Traditionalism, 43 Stan. L. ReV. 1035 (1991); Henry P. Monaghan, Our Perfect Constitution, 56 N.Y.U. L. Rev. 353 (1981); Michael J. Perry, The Authority of Text, Tradition, and Reason: A Theory of Constitutional “Interpretation," 58 S. CAL. L. REV. 551 (1985); Jack N. Rakove, Fidelity Through History (Or to It), 65 FORDHAM L. REV. 1587 (1997); David A.J. Richards, Interpretation and Historiography, 58 S. CAL. L. REV. 489 (1985); Terrence Sandalow, Constitutional Interpretation, 79 Mich. L. ReV. 1033 (1979); Frederick Schauer, Precedent, 39 Stan. L. ReV. 571 (1987); David A. Strauss, Common Law Constitutional Interpretation, 63 U. CHI. L. REV. 877 (1996); Cass R. Sunstein, Burkean Minimalism, 105 Mich. L. REV. 353 (2006) [hereinafter Sunstein, Minimalism]; Adrian Vermeule, Common-Law Constitutionalism and the Limits of Reason, 107 Colum. L. REV. 1482 (2007); Ernest Young, Rediscovering Conservatism: Burkean Political Theory and Constitutional Interpretation, 72 N.C. L. REV. 619 (1994).

${ }^{5}$ David Strauss, The Living Constitution (Geoffrey R. Stone ed., 2010); Sunstein, MAnY Minds, supra note 4; William N. Eskridge, Jr., Sodomy and Guns: Tradition as Democratic Deliberation and Constitutional Interpretation, 32 HARV. J.L. \& PUB. POL'Y 193 (2009); Vermeule, supra note 4, at 1482. For a more detailed account of scholarly treatment of traditionalism during the Roberts Court's first five terms, see infra Part II.C. See also generally supra note 4 (collecting traditionalist sources).

${ }^{6}$ This article represents the first installment in a larger, ongoing investigation of the Supreme Court's current and historical treatment of constitutional traditionalism. The larger project seeks to identify and code for every instance in which the Supreme Court has employed traditionalism as an interpretive tool in constitutional cases throughout the history of the Court. 
The arrival of the fifth anniversary of the Roberts Court in October 2010 presents a valuable opportunity to evaluate that Court's jurisprudential trends. ${ }^{7}$ Five years of experience with the Roberts Court provides a body of work against which to test some of the assumptions about the Court's philosophy and jurisprudence that accompanied its formation with the swearing-in of John G. Roberts, Jr. as Chief Justice on September 29, 2005. ${ }^{8}$ One of the most hotly discussed issues associated with Chief Justice Roberts' nomination - as well as those of many of his colleagues on the Court - was the new Chief's view of the judiciary's role in American constitutionalism. The Chief Justice most famously analogized judges to baseball umpires, officials tasked with objectively applying a static set of rules to different factual circumstances in order to resolve specific cases, rather than to "make law" or otherwise legislate from the bench. ${ }^{9}$ This position garnered much popular support for its relative humility in the exercise of significant power and signaled not only that Chief Justice Roberts' judicial philosophy was conservative insofar as it sought to restrain judicial authority, but that the Chief Justice was keenly aware that the approach of individual Justices and of the Court as a whole to constitutional interpretation is crucial to the Court's contribution to American government.

This article offers some insight into the constitutional jurisprudence of the Roberts Court by analyzing that Court's traditionalist activity in its first halfdecade. ${ }^{10}$ Part II begins with a description of the concept of tradition in general and of traditionalism in particular as a constitutional interpretive tool. It then briefly highlights the constitutional traditionalism literature, with special attention to contributions made during the Roberts Court's tenure, in order to demonstrate the

${ }^{7}$ See generally Symposium, Chief Justice Roberts' Influence on the Supreme Court, 40 STETSON L. REV. 661 (2011) (evaluating the first five years of the Roberts Court).

${ }^{8}$ See Roberts Sworn in as Chief Justice, CNN.COM (Sept. 29, 2005, 11:49 PM), http://articles.cnn .com/2005-09-29/politics/roberts.nomination_1_judge-roberts-confirmation-votes-john-g-roberts?_s= PM:POLITICS

${ }^{9}$ See Confirmation Hearing on the Nomination of John G. Roberts, Jr. To Be Chief Justice of the United States: Hearing Before the S. Comm. on the Judiciary, 109th Cong. 55 (2005) ("Judges are like umpires. Umpires don't make the rules, they apply them. The role of the umpire and a judge is critical. They make sure everyone plays by the rules, but it is a limited role.").

${ }^{10}$ This project is not designed to advance a normative position regarding the value of traditionalism, nor does it offer a comparison between the Roberts Courts and any of its predecessors. Such comparative analyses will be part of the ongoing traditionalism project described supra note 6 . Instead, it provides a foundation of previously unavailable information that is not only informative in its own right, but that may also be used as a catalyst for future and more robust inquiries into the role of traditionalism in the Court's constitutional jurisprudence. 
depth and vitality of the current traditionalism debate. Part III outlines the empirical (content analysis) methodology used to identify cases in which traditionalism was employed as an interpretive method, the nature of the resultant data, and the various safeguards utilized to preserve informational reliability and accuracy. Part IV offers some preliminary findings relating to three broad questions about the use of traditionalism by the Roberts Court: (1) the frequency with which the Court employs traditionalism in constitutional analyses; (2) the breadth of constitutional provisions that the Court has interpreted using traditionalism; and (3) the identity of those Roberts Court Justices who have relied on traditionalism in evaluating different constitutional provisions. The resultant data indicate that traditionalism is used by the Roberts Court often, across a wide range of constitutional questions, and by a diverse group of Justices, in a variety of contexts. In light of these preliminary findings, Part $\mathrm{V}$ considers some opportunities for future research made possible by this study.

\section{Tradition AND TraditionalisM}

\section{A. Tradition}

Any discussion of traditionalism and American constitutional jurisprudence must first consider what is meant by the concept of tradition. Significant time and intellectual capital have been devoted to tradition in a wide array of social sciences, including religion, anthropology, and sociology. ${ }^{11}$ Perhaps not surprisingly, law, while borrowing from these conversations, has employed tradition in its own way. ${ }^{12}$ But what, if anything, is commonly meant by reference to the concept of tradition? Although many legal scholars have offered definitions of tradition, sometimes with conflicting results, ${ }^{13}$ Professor Martin Krygier offers a three-part description of tradition from which some common threads emerge. ${ }^{14}$

${ }^{11}$ See, e.g., Jaroslav Pelikan, The Vindication of Tradition (1984); EdWARd Shils, Tradition (1981).

${ }^{12}$ Much that has been said about the importation of other disciplines into the law is critical of lawyers' ability and willingness to adhere to the accepted methods of those disciplines. A common example of this criticism is with regard to lawyers' use of historical materials and information in legal argument and analysis. See, e.g., Alfred H. Kelly, Clio and the Court: An Illicit Love Affair, 1965 SuP. CT. Rev. 123, 132 (1965) (criticizing the use of history by the Supreme Court as being "of the law-office variety").

${ }^{13}$ Compare Brown, supra note 4, at 182 (describing her definition of tradition in constitutional interpretation as not among the "more common meanings" of the term in that it does not "presuppose that the practice at issue has withstood the test of time" in order to qualify as a tradition), with Perry, supra note 4, at 558 (quoting A. MACINTYRE, AFTER VIRTUE 207 (1981)) (emphasizing the timedependent nature of tradition in defining the term to represent "a particular history or narrative, in which the central motif is an aspiration to a particular form of life ... in MacIntyre's terms, 'an historically 
Without attempting to provide anything approaching a thorough exposition of Krygier's work, two points are worth noting at the outset: First, Krygier's three elements of tradition are consistent with the work of many other distinguished scholars, such that even a brief articulation of Krygier's description offers a fairly inclusive account of the concept of tradition. Second, Krygier's formulation offers a useful starting point for the next phase of the discussion, the differentiation, at least in theory, of "traditionalism" - the use of the concept of tradition in constitutional interpretation-from other influential methods of constitutional interpretation. Once traditionalism is identified as an independent interpretive enterprise, its relevance to modern constitutional theory becomes more readily apparent.

Krygier identifies three "characteristics or elements" of tradition, each of which he contends is "found in almost all legal systems": "pastness," "authoritative presence," and "transmission.", For Krygier, "pastness" is the quality of being "composed of elements drawn from the real or an imagined past." "This quality is "central" to the existence of a tradition in a way that it is not for an "act, rule, or

extended, socially embodied argument'-about how that form of life is to be cultivated and revised.") (emphasis added).

${ }^{14}$ Krygier's discussion of tradition is not focused on the question meant to be addressed here, namely how or to what degree "particular legal systems," in this case the American system and, more specifically, the American Constitution, should be treated as "embody[ing] traditions." It is instead primarily concerned with how "the nature and behavior of traditions in social life" can help us understand "much that is most central to and characteristic of the nature and behavior of law." Martin Krygier, Law as Tradition, 5 LAW \& PHIL. 237, 239 (1986). This is, without question, a broader inquiry largely beyond the scope of the present analysis. This is not to say, however, that Krygier does not have anything of importance to offer with respect to the aims of this project. Although not specifically discussing constitutional law, Krygier argues for the inherent pastness of the law, pointing out that legal systems have institutionalized a focus on the past and its maintenance through reliance on authoritative materials in legal decision-making. Id. at 241 ("In law, however, past-maintenance is institutionalized ... participants in legal traditions are required to justify their arguments in terms of acceptable interpretations of . . . authoritative materials."). He goes on to argue that the past has an "authoritative presence" in the law, as the past is often treated as "a vast storehouse to be searched for solutions to present problems." Id. at 245,248 . This is in contrast to the "historian, qua historian," who is seeking "clues to events in the otherwise hidden past," independent of their value in providing authoritative meanings and input to current questions. Id. at 250. Finally, Krygier argues that legal systems have formalized and institutionalized the "transmission" of past elements to the present through the maintenance of past, authoritative materials. Id. These connections between the law and tradition serve as (at least tacit) support for the underlying theme I mean to pursue here, namely that tradition is, for better or worse, an important feature of constitutional jurisprudence and, as such, should be explored not only theoretically, but empirically, in order to better understand its normative contribution.

${ }^{15} I d$. at $239-40,250$.

${ }^{16} I d$. 
principle." ${ }^{17}$ Put another way, the process of identifying a tradition requires some investigation into the history of the relevant community; a tradition cannot "openly be made retrospective."18 This view is shared by the prominent sociologist, Professor Edward Shils, who described as an essential feature of a tradition that it be "something which was created, was performed or believed in the past, or which is believed to have existed or to have been performed or believed in the past." 19

The "authoritative presence" of tradition describes the extent to which "the real or imagined past plays a present normative or authoritative role in one's values or beliefs." ${ }^{20}$ By this measure, it is not enough to constitute a tradition to say that something is past - that past phenomenon must also have a present influence. Shils addressed this feature of tradition by explaining that a tradition is more than the consistent belief over time of a specific set of ideas; it also includes a "formative" element whereby subsequent (i.e., current) opinion or belief is influenced by those past ideas. ${ }^{21} \mathrm{~A}$ similar point was made by Edmund Burke, who is widely regarded as among the foremost traditionalists in political and legal theory, when he called for "reverence to antiquity" in the formation of new government, including reliance on "analogical precedent, authority and example" from the past to inform modern thought. ${ }^{22}$

Finally, the third element Krygier cites as central to the existence of a tradition is "transmission." 23 Far from identifying as traditions all instances in which the past maintains an authoritative presence, Krygier explains that tradition depends on "real or imagined continuities between past and present." 24 The importance of transmission to the existence of a tradition is evident in Shils' (selfdescribed "bare") definition of a tradition as "anything which is transmitted or

${ }^{17} \mathrm{Id}$. at 240 . He also notes that a tradition can be originated, and as such is not necessarily backwardlooking at its point of origin, but from its inception on will include an element of history or pastness. See id. at 241; but see Brown, supra note 4, at 182 (defining tradition such that it does not "presuppose that the practice at issue has withstood the test of time").

${ }^{18}$ Krygier, supra note 14, at 241.

${ }^{19}$ SHILS, supra note 11 , at 13.

${ }^{20}$ Krygier, supra note 14, at 246.

${ }^{21}$ SHILS, supra note 11 , at 41.

${ }^{22}$ BURKE, supra note 4 , at 53.

${ }^{23}$ Krygier, supra note 14, at 250.

${ }^{24} I d$. 
handed down from the past to the present." ${ }^{, 25}$ In the context of tradition's role in law and politics, Burke cited the same transitory quality when he advocated for a political system based on the "inheritance from our forefathers" of "[t]he institutions of policy," and for the "benefits, from considering our liberties in the light of an inheritance." 26 Burke's concept of transmission as an important part of traditionalism also appears in modern constitutional scholarship, including the work of Professor Barry Friedman and attorney Scott Smith, who contend that "[t]rue fidelity to the Constitution requires that we be faithful to what history reveals as this generation's deepest, most enduring commitments," which are likely to be "passed along to us through the generations." 27

\section{B. Traditionalism}

The purpose in highlighting these common features of tradition is not to offer substantive support or criticism for any single definition, but merely to introduce some of tradition's core elements as a segue to discuss its relevance in current constitutional law and scholarship. Tradition is a foundational concept in the

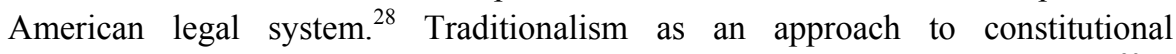
interpretation has been part of Supreme Court jurisprudence for over a century. ${ }^{29} \mathrm{It}$ applies the concept of tradition to guide current application of the law, and has been described more broadly as the reliance on "history and tradition" 30 to give

\footnotetext{
${ }^{25}$ SHILS, supra note 11 , at 12.

${ }^{26}$ BURKE, supra note 4 , at 53, 54.

${ }^{27}$ Barry Friedman \& Scott B. Smith, The Sedimentary Constitution, 147 U. PA. L. REV. 1, 6-7 (1998) (emphasis added).

${ }^{28}$ Professor Krygier explained the strong connections between law and tradition as follows:
}

Law is a profoundly traditional social practice. This is not merely to say that particular legal systems embody traditions, which of course no one would deny. To understand much that is most central to and characteristic of the nature and behavior of law, the "time-free" staples of modern jurisprudence are not enough. One needs to understand the nature and behavior of traditions in social life.

Krygier, supra note 14, at 239. The practice and training of lawyers is further evidence of the connection between tradition and the law. Legal arguments are almost always premised on past events, and the casebook method of legal education trains new lawyers to look to the past for answers to modern questions.

${ }^{29}$ The precise scope of traditionalism's influence as an interpretive tool is part of the larger, ongoing empirical project discussed supra note 6 .

${ }^{30}$ See Thomas E. Baker, Constitutional Theory in a Nutshell, 13 WM. \& MARY BILL RTS. J. 57, 76-79 (2004). 
meaning to constitutional language. More significant than the precise definition of traditionalism for present purposes, however, are the distinctions to be drawn between traditionalism and other widely discussed interpretive canons. Constitutional theory is often described as consisting of two distinct and entrenched camps: "living constitutionalism" and "originalism.",

Living constitutionalism advocates a dynamic approach to constitutional interpretation, where contemporary notions of justice and societal needs drive constitutional meaning. ${ }^{32}$ To be sure, living constitutionalism is not a monolith; it incorporates a variety of interpretive methodologies and perspectives. ${ }^{33}$ There is,

${ }^{31}$ See Antonin Scalia, A Matter of InTERPREtation: Federal Courts AND the LaW 38 (1997) ("[T]he Great Divide with regard to constitutional interpretation is ... that between original meaning and current meaning."); Friedman \& Smith, supra note 27, at 1, 4 ("Until the latter half of the nineteenth century, constitutional theory and practice sought a relative continuity with the Founders' design. Since that time, however ... the idea of a 'living Constitution,' one that is interpreted as evolving to keep pace with current events - has competed with originalism.").

While this bilateral description of constitutional theory is, of course, an oversimplification, it is adequate to demonstrate the bounds of traditionalist theory by delineating where other, more frequently discussed or well-known theories end and traditionalism begins.

${ }^{32}$ Friedman \& Smith, supra note 27, at 10 (describing living constitutionalism as "the practice of interpreting the Constitution, usually in a nonhistorical way, to meet the needs of the present."). The concept of living constitutionalism was addressed as early as 1925 by Edward Corwin:

The proper point of view from which to approach the task of interpreting the $[C]$ onstitution is that of regarding it as a living statute, palpitating with the purpose of the hour, reenacted with every waking breath of the American people, whose primitive right to determine their institutions is its sole claim to validity as a law and as the matrix of laws under our system.

Edward S. CORwin, American CONSTITUTIONAL History 108 (Alpheus Mason \& Gerald Garvey eds., 1964).

${ }^{33}$ The umbrella of living constitutionalism spans a number of theories of constitutional adjudication that are themselves distinct from one another. For instance, both moral reasoning and pragmatism fit within the ambit of living constitutionalism as it is here described, yet each espouses a very different approach to resolving constitutional questions. Compare Ronald Dworkin, FreEdom's Law: THE Moral READING OF THE AMERICAN CONSTITUTION 2 (1996) ("The moral reading [of the Constitution] proposes that we all—judges, lawyers, citizens - interpret and apply these abstract clauses [e.g., the Free Speech Clause of the First Amendment] on the understanding that they invoke moral principles about political decency and justice."), with Richard A. Posner, Pragmatic Adjudication, 18 CARDOZO L. REV. 1, 4 (1996) (defining pragmatic constitutional adjudication as "always [trying] to do the best [the judge] can do for the present and the future, unchecked by any felt duty to secure consistency in principle with what other officials have done in the past") (emphasis added). For present purposes, however, it is not necessary to do any more than acknowledge these different approaches to living constitutionalism, as they are each distinct from traditionalism for essentially the same reasons; unlike traditionalism, all forms of living constitutionalism prioritize the present-day needs and values of society to justify constitutional meaning, while traditionalism looks first for past practices and attitudes that have been 
however, an identifiable core to living constitutionalism-the concept that constitutional meaning must resonate in the political, cultural, and social environment in which the interpreters live. Thus, even for examples of living constitutionalism that employ historical methodologies, such as the theory of common law constitutionalism advocated by David Strauss and others, ${ }^{34}$ a necessary feature of living constitutionalism is the possibility of an abrupt and discontinuous break from the past. ${ }^{35}$ In this way, living constitutionalism is theoretically distinct from traditionalism's "pastness," 36 which is designed to restrain judges from relying on modern notions of what is a good or just result at the expense of deference to preexisting norms and customs. ${ }^{37}$ Put another way, while common law constitutionalism offers a concept of living constitutionalism that may overlap with traditionalism in its incorporation of traditional sources like precedent, ${ }^{38}$ there are important points of divergence between the two. An approach modeled on the common law (common law constitutionalism) tolerates ahistorical

carried forward with reverence into the present, a far more limiting and conservative approach to interpretation than that of living constitutionalism generally.

${ }^{34}$ See Strauss, supra note 4 (describing his theory of common law constitutionalism).

${ }^{35}$ Id. at 934-35 ("The common law approach [to constitutional interpretation] . . forth rightly accepts, without apology, that we depart from past under standings [sic], and that we are often creative in interpreting the text. .. . [P]roperly understood the common law method does not immunize the past from sharp, critical challenges.").

${ }^{36}$ Krygier, supra note 14 , at 240.

${ }^{37}$ Edmund Burke described this facet of traditionalism's pastness in his praise for the virtues of the British Constitution:

We are afraid to put men to live and trade each on his own private stock of reason; because we suspect that this stock in each man is small, and that the individuals would do better to avail themselves of the general bank and capital of nations and of ages.

BURKE, supra note 4, at 59.

${ }^{38}$ A potential example of traditionalism and living constitutionalism overlapping can be seen in Justice Harlan's famous dissent in Poe v. Ullman, 367 U.S. 497, 511 (1961). In his well-known discourse on the meaning of due process, Justice Harlan cites as relevant sources of information "what history teaches are the traditions from which [the country] developed as well as the traditions from which it broke." Id. at 542. He goes on to explain that "[e]ach new claim to Constitutional protection must be considered against a background of Constitutional purposes, as they have been rationally perceived and historically developed." Id. at 544. While Justice Harlan's discussion about tradition itself appears to invoke some elements of living constitutionalism as well as traditionalism, his later discussion of constitutional purpose and rationality are more clearly evocative of a living constitutionalist viewpoint. 
or even counter-historical justifications in a way that traditionalism does not. ${ }^{39}$ Living constitutionalism is similarly inconsistent with the "authoritative presence" and "transmission" elements of tradition and traditionalism. Traditionalism's concern with the past's authority in, and continuity with, the present results in an inherent resistance to rapid or drastic change. ${ }^{40}$ Living constitutionalism, by contrast, is far less concerned with maintaining doctrinal consistency, focusing instead on the current cultural, political, and social effects of its decisions. ${ }^{41}$

The interpretive method more likely to be conflated with traditionalism is "originalism," the notion that the underlying "understandings and intentions" of the Constitution at the time it was written and ratified are the best sources of information for discerning its meaning. ${ }^{42}$ Although many attempts to rely on history or tradition in interpreting the Constitution have been criticized as overly reliant on the Founding Era, ${ }^{43}$ traditionalism, at least as a theoretical matter, is not.

${ }^{39}$ I am grateful to Joel Goldstein and Bill Marshall for bringing the complexities of the relationship between living constitutionalism - especially common law constitutionalism — and traditionalism into clearer focus. I alone am responsible for any remaining confusion.

${ }^{40}$ See generally BURKE, supra note 4, at 63 ("[Traditionalist reform] might take up many years. Without question it might, and it ought. It is one of the excellencies of a method in which time is amongst the assistants, that its operation is slow, and in some cases almost imperceptible.").

${ }^{41}$ See Friedman \& Smith, supra note 27, at 10; CoRWIN, supra note 32, at 108.

${ }^{42}$ Friedman \& Smith, supra note 27, at 9-10 (describing originalism as "the practice of explicitly returning to Founding-era understandings and intentions to reach conclusions about what the Constitution means today"). Much like with the moniker of living constitutionalism, originalism is used broadly here to include what have been described elsewhere as distinct theories of interpretation such as textualism, which operates under the principle that the only authoritative source for constitutional meaning is the text of the document, see Michael GerhardT, STEPHEN M. GRiffin \& ThOMAS D. Rowe, Jr., Constitutional Theory: ARguments AND PersPectives 175 (3d ed. 2007) (describing the "pure" textualist position, and acknowledging that many textualists also refer to relevant historical evidence in aid of their interpretation, thus blurring the lines somewhat between originalism and textualism), and even structural interpretation, which is less committed to a particular point in time than originalism, but that does focus on the textual meaning of certain provisions of the Constitution in light of the structure of the government it creates. See, e.g., Charles Black, Structure And RELATIONSHIP IN CONSTITUTIONAL LAW (1969) (defending the process of structural analysis in constitutional interpretation). Notwithstanding the differences among these various approaches, it is acceptable to group them under a single heading for present purposes because at bottom, while they all may be different from one another, they are distinguishable from traditionalism on similar grounds. Originalism, textualism, and structuralism all operate within a relatively static understanding of the constitutional text, and at minimum do not purport to treat constitutional meaning as a product of traditional practices or beliefs beyond those articulated in the document. As such, it does no harm to our project of outlining the parameters of traditionalism to combine all of the above theories under the single heading of originalism.

${ }^{43}$ Larry Kramer, Fidelity to History - and Through It, 65 FORDHAM L. REV. 1627, 1628 (1997) (“[C]onstitutional theory can fairly be described as 'Founding obsessed' in its use of history."). 
While traditionalism may reach common conclusions, in certain instances, with originalism (the Founding is, after all, both historical and a source of many American political traditions), ${ }^{44}$ traditionalism in the truest sense does not give priority to a specific time period or group of past actors but is open to learning from a variety of traditional and historical sources (such as the "common law tradition," "traditional ... Anglo-American courts," and "traditional executive power," to name a few $)^{45}$ over varying time frames. ${ }^{46}$

Defining traditionalism generally and offering points of distinction between it and other theories of constitutional interpretation does not, in and of itself, paint a full picture of traditionalism's place in constitutional theory and jurisprudence. Like living constitutionalism and originalism, traditionalism is not a monolithic enterprise; it includes a wide variety of different applications of the concept of tradition to constitutional problems. At its most theoretical, traditionalism can be viewed as a preference for relying on popular, time-honored practices and ideas to inform our thinking about political and legal institutions generally, including the Constitution. ${ }^{47}$ In the constitutional law context, this broad perspective counsels

${ }^{44}$ LACKLAND H. BloOM, JR., Methods of Interpretation 133 (2009) ("If [traditional] practice extends back to the framing generation, such practice may be understood as strong evidence of the original understanding."); Freidman \& Smith, supra note 27, at 37 (describing how areas of constitutional law with less of a jurisprudential history will essentially be interpreted in accordance with their original meaning: "Suppose, for example, that a question should arise as to the meaning of the Third Amendment .... [B]ecause we have not had cause to consider this question much in our history, inevitably we find ourselves returning to, and curious about, original understandings of this particular amendment.").

${ }^{45}$ Melendez-Diaz v. Massachusetts, 129 S. Ct. 2527, 2534 (2009) (considering "common law tradition" of live testimony in court as part of an analysis under the Sixth Amendment); Summers v. Earth Island Inst., 555 U.S. 488, 492 (2009) (referring to the "traditional role of Anglo-American courts" in analyzing an Article III standing issue); Free Enter. Fund v. Pub. Co. Accounting Oversight Bd., $130 \mathrm{~S}$. Ct. 3138, 3152 (2010) (referring to the "traditional executive power" in discussing the removal of executive officers).

${ }^{46}$ Two examples of historical sources that are well suited for traditionalist reasoning but poor fits for an originalist analysis are ongoing history and precedent, both of which are highly relevant to the Court's substantive due process jurisprudence. Compare Lawrence v. Texas, 539 U.S. 558, 571-72 (2003) (explaining that "we think that our laws and traditions in the past half century are of most relevance here. These references show an emerging awareness that liberty gives substantial protection to adult persons in deciding how to conduct their private lives in matters pertaining to sex."), with Lawrence, 539 U.S. at 598 (Scalia, J., dissenting) (contending that "an 'emerging awareness' is by definition not 'deeply rooted in this Nation's history and tradition[s]'”) (quoting majority opinion, $i d$.).

${ }^{47}$ See BURKE, supra note 4, at 53-54 ("All the reformations we have hitherto made have proceeded upon the principle of reverence to antiquity; and I hope, nay, I am persuaded that all those which may be possibly made hereafter, will be carefully formed upon analogical precedent, authority, and example.... $[T]$ he idea of inheritance furnishes a sure principle of conservation, and a sure principle of transmission; 
against drastic and abrupt changes in the structure and function of government. It advocates for gradual, iterative alterations of the constitutional status quo based on a corresponding development of the elements of tradition, such as collective wisdom and experience. ${ }^{48}$ Some of the more concrete examples of traditionalism's impact in this regard are evident in the Court's reliance on "traditional executive power" and "traditional state functions" in interpreting the scope and interplay of Articles I and II. ${ }^{49}$

Traditionalism also influences constitutional law by providing content to specific constitutional rights. ${ }^{50}$ The most commonly discussed of these influences is tradition's role in defining individual substantive rights under the Fourteenth Amendment's Due Process Clause. ${ }^{51}$ But traditionalism also impacts a variety of

without at all excluding a principle of improvement.... By a constitutional policy, working after the pattern of nature, we receive, we hold, we transmit our government and our privileges.... The institutions of policy, the goods of fortune, the gifts of providence, are handed down to us, and from us, in the same course and order. Our political system is placed in a just correspondence and symmetry with the order of the world, and with the mode of existence decreed to a permanent body composed of transitory parts; wherein ... the whole, at one time, is never old, or middle-aged, or young, but, in a condition of unchangeable constancy, moves on through the varied tenor or perpetual decay, full renovation, and progression.... By adhering in this manner and on those principles to our forefathers, we are guided not by the superstition of antiquarians, but by the spirit of philosophic analogy.").

${ }^{48}$ See Young, supra note 4, at 655 ("Slow reform, for Burke, minimized the risks of change by proceeding in small increments that could each be tested for consistency with the overall structure of government and society."); id. at 653 ("Nor did Burke see his traditionalism as inconsistent with reform. For Burke, 'the idea of inheritance furnishes a sure principle of conservation, and a sure principle of transmission, without at all excluding a principle of improvement. It leaves acquisition free, but it secures what it acquires." (citing BURKE, supra note 4, at 83-84)).

${ }^{49}$ See, e.g., Free Enter. Fund v. Pub. Co. Accounting Oversight Bd., 130 S. Ct. 3138, 3152 (2010); United Haulers Ass'n, Inc. v. Oneida-Herkimer Solid Waste Mgmt. Auth., 550 U.S. 330, 344 (2007) ("We should be particularly hesitant to interfere with the Counties' efforts under the guise of the Commerce Clause because "[w]aste disposal is both typically and traditionally a local government function."); United States v. Lopez, 514 U.S. 549, 577 (1995) (Kennedy, J., concurring) ("Were the Federal Government to take over the regulation of entire areas of traditional state concern, areas having nothing to do with the regulation of commercial activities, the boundaries between the spheres of federal and state authority would blur and political responsibility would become illusory."); National League of Cities v. Usery, 426 U.S. 833,852 (1976) ("[I]insofar as the challenged amendments operate[d] to directly displace the States' freedom to structure integral operations in areas of traditional governmental functions, they [were] not within the authority granted Congress by [the Commerce Clause].").

${ }^{50}$ See, e.g., Cass Sunstein, Due Process Traditionalism, 106 Mich. L. Rev. 1543 (2008) (critiquing the use of traditionalism in due process cases).

${ }^{51}$ See Dist. Attorney's Office v. Osborne, 129 S. Ct. 2308, 2320 (2009) (acknowledging the test for a due process violation as whether the State's conduct "offends some principle of justice so rooted in the traditions and conscience of our people as to be ranked as fundamental"). 
other rights, including identifying which forums offer the greatest protections for speech $^{52}$ and preserving individuals' rights to be free from unreasonable searches under the Fourth Amendment. ${ }^{53}$

Additionally, traditionalism includes the incorporation of common law traditions into constitutional law. While common law traditions are similar to other sources of tradition in that they impact the scope of individual constitutional rights, such as criminal defendants' rights to confront witnesses and to trial by jury, ${ }^{54}$ they also serve other functions. The common law tradition of due process, for instance, informs our modern constitutional understanding of the judicial system. ${ }^{55}$ The Court's reliance on precedent under the doctrine of stare decisis is another form of common law traditionalism. ${ }^{56}$ Although it is distinct in ways that render it largely outside the scope of this project, ${ }^{57}$ the use of precedent is inherently traditionalist, as it relies on the collective wisdom of existing decisions to support what are typically gradual, discreet developments in the law. ${ }^{58}$

52 See Pleasant Grove City v. Summum, 555 U.S. 460, 464 (2009) (relying in large part for its First Amendment analysis on whether a public park was a "traditional public forum").

${ }^{53}$ See Virginia v. Moore, 553 U.S. 164, 171 (2008) (relying on "traditional standards" for determining reasonableness under the Fourth Amendment).

${ }^{54}$ See, e.g., Melendez-Diaz v. Massachusetts, 129 S. Ct. 2527, 2534 (2009) (invoking the "common-law tradition" of live testimony in interpreting the Confrontation Clause); Cunningham v. California, 549 U.S. 270, 281 (2007) (acknowledging that the Sixth Amendment right to a jury trial "is rooted in longstanding common-law practice").

55 See, e.g., Caperton v. A.T. Massey Coal Co., 129 S. Ct. 2252, 2260 (2009) (citing "the traditional common-law prohibition on direct pecuniary interest" in an analysis of judicial bias under the Due Process Clause).

${ }^{56}$ See Anthony T. Kronman, Precedent and Tradition, 99 YALE L.J. 1029 (1990) (describing the "legal practice that we call the rule of precedent" as "merely one expression" of traditionalism); Strauss, supra note 4 (advocating for an approach to constitutional interpretation similar to common law reasoning through precedent). While reliance on precedent is traditionalist, that does not mean that broader theories of common law constitutional adjudication are similarly traditionalist. As mentioned supra notes 33-38 and accompanying text, common law constitutionalism tolerates the abandonment of precedential reasoning in certain situations where traditionalism would not.

${ }^{57}$ For a detailed discussion of the differences between stare decisis and other forms of traditionalism, and more specifically how those differences counsel in favor of excluding precedential reasoning from the instant investigation of traditionalism in the Roberts Court, see discussion infra Part III.B.

${ }^{58}$ See STRAUSS, supra note 5, at 40 (describing the common law approach as being "governed by a set of attitudes: attitudes of humility and cautious empiricism"); Young, supra note 4, at 656 (describing Burke's support for gradual, lasting change in the law through traditionalism as "reminiscent of the methods of the common law"). 
In short, traditionalism-like its theoretical counterparts - encompasses a range of interpretive methodologies. The existence of potentially distinct constituent parts, however, is not grounds for overlooking the whole. Despite manifesting itself in varied ways in American constitutional jurisprudence, traditionalism is a coherent theory of interpretive thought, defined by the elements of tradition articulated by Burke, Krygier, and Shils, among others.

\section{Modern Traditionalism Scholarship}

The Supreme Court's use of constitutional traditionalism is not, however, worthy of critical review or study merely because traditionalism may be defined as a distinct constitutional theory. Rather, constitutional traditionalism merits immediate attention because it is a current topic of significant and wide-ranging scholarly, as well as judicial, discourse. Although the roots of academic discourse about traditionalism can be traced back at least fifty years to Alexander Bickel in The Least Dangerous Branch, ${ }^{59}$ the traditionalism debate has continued unabated ever since, including during the first five years of the Roberts Court.

The significant scholarly activity devoted to traditionalism in the last five years supports the need for further consideration of traditionalism and the Roberts Court both theoretically and - as is the subject of this project—empirically. In the last two years alone, two prominent constitutional scholars have published books in which they offer substantial treatments of traditionalism. In A Constitution of Many Minds, Cass Sunstein devotes the largest portion of his discussion of three schools of interpretation (traditionalism, populism, and cosmopolitanism) to a form of traditionalism he calls "Burkean Minimalism." ${ }^{, 60}$ According to Sunstein, although Burkean Minimalism is vulnerable to a number of potential criticisms based on the indeterminacy, subjectivity, and uncertain normative value of traditions, ${ }^{61}$ there are certain conditions and contexts in which traditionalist reasoning is a defensible and, arguably, desirable method of constitutional interpretation. ${ }^{62}$ David Strauss offers

\footnotetext{
${ }^{59}$ BICKEL, supra note 4. See also sources collected supra note 4. In addition to the current empirical project tracing the Court's use of traditionalism back at least 80 years, I am also currently engaged in a project surveying the history of traditionalism scholarship.

${ }^{60}$ SUNSTEIN, MANY MindS, supra note 4, at 35-60.

${ }^{61} I d$. This position is consistent with Sunstein's prior work on traditionalism. See, e.g., Sunstein, supra note 50; Sunstein, Minimalism, supra note 4; Cass R. Sunstein, Against Tradition, in THE Communitarian Challenge to Liberalism 207 (Ellen Frankel Paul, Fred D. Miller, Jr. \& Jeffrey Paul eds., 1996).

${ }^{62}$ Sunstein cites separation of powers as an area where traditionalism's reliance on past practices is more likely to lead to defensible results, and the area of individual rights, especially the Equal Protection Clause, as an example of a constitutional context that is poorly suited to traditionalist analysis.
} 
his portrayal of traditionalism in The Living Constitution, his most recent defense of common law constitutionalism. ${ }^{63}$ Strauss' arguments for the value of a common law approach to constitutional interpretation are expressly Burkean in their focus on judicial "humility" and "cautious empiricism" to address complex constitutional problems. ${ }^{64}$ Although Strauss acknowledges the authority of the text in reading the Constitution, ${ }^{65}$ he advocates for a dynamic approach to constitutional interpretation that is tempered by traditionalist notions but that ultimately goes beyond "pure" Burkean traditionalism to incorporate notions of "fairness and good policy." 66

In addition to Sunstein and Strauss, a number of other prominent constitutional law scholars have also recently tackled questions about traditionalism's normative justifications. Adrian Vermeule critiques the argument that applying Condorcet's Jury Theorem to traditionalist decision-making reveals information and efficiency benefits for judges who employ traditionalism in constitutional cases. ${ }^{67} \mathrm{He}$ concludes that Condorcet's Theorem better supports the

\begin{abstract}
Under some constitutional provisions, above all the Equal Protection Clause, the Burkean approach is hard or perhaps impossible to square with entrenched understandings in American constitutional law .... But in other domains, . . . the areas of separation of powers and national security, for example, Burkean minimalism deserves to have, and indeed has had, a major role, as the Court has proceeded via small steps and with close attention to institutional practices extending over time.
\end{abstract}

Sunstein, Minimalism, supra note 4, at 400-01.

${ }^{63}$ STRAUSS, supra note 5, at 40-42.

${ }^{64} \mathrm{Id}$. at 40-41 (explaining that "[t] hese attitudes [of humility and cautious empiricism], taken together, make up a kind of ideology of the common law . . . . The most famous exponent of this ideology was the British statesman Edmund Burke ....").

${ }^{65} \mathrm{Id}$. at 103 ("[O]ne of the absolute fixed points of our legal culture is that we cannot . . say that the text of the Constitution doesn't matter.").

${ }^{66}$ Id. at 43 .

${ }^{67}$ See Vermeule, supra note 4. Vermeule expressly refers to common law constitutionalism as his point of interest in the article, but goes on to concede that the lines between common law constitutionalism and traditionalism more generally are, at best, blurred:

As mentioned above, a central ambiguity within common law constitutionalism is the slippage back and forth between judicial traditionslines of precedent or doctrine - on the one hand, and broader societal traditions on the other. In principle, a precedent need not draw upon tradition, and a tradition need not be embodied in a precedent. Sometimes common law constitutionalists explicitly distinguish precedent from tradition. Some proponents of tradition, especially those who see tradition as a kind of spontaneous order, explicitly deny that praise for tradition implies praise for 
conclusion that the Framers and the legislature are at least as likely as the judiciary to possess the informational and efficiency advantages of a tradition-based interpretive model. ${ }^{68}$ William Eskridge has also been critical of traditionalism in his recent work. ${ }^{69} \mathrm{He}$ treats tradition both as a stand-alone interpretive model and an instrumentality of originalism ${ }^{70}$ and concludes that problems of anachronism, "cherry-picking" of traditions, and democratic illegitimacy render traditionalism in large measure unworkable. ${ }^{71} \mathrm{He}$ nevertheless finds some redemptive value in viewing tradition as an "ongoing democratic deliberation," in which "the authoritative value of tradition is greatest when it is recognized and elaborated by legislatures after open and public deliberation." ${ }^{, 72}$ Not only does this approach to

\begin{abstract}
precedent, which they see as the positive lawmaking of a centralized lawmaker (such as the Supreme Court).

However, the lines frequently blur, both in theory and in practice. In theory, a main claim of common law constitutionalism is that a stream of precedent that has stood the test of time is a kind of tradition, and deserves respect for the same reasons as tradition. In practice, it has been argued, for example, that the Warren Court was a "common law court," basing its decisions on experience. In some cases, this claim is supported by pointing to earlier precedents on which the Warren Court drew. Where the Warren Court overruled or broke dramatically from precedent, however, the claim is supported by pointing to larger political and social traditions said to be inconsistent with the discarded precedent. Thus, for example, the innovative decisions requiring a "one person, one vote" standard in reapportionment cases are justified by pointing to a broader historical trend toward expansion of the formal franchise. Common law constitutionalism that ranges over both precedent and tradition has multiple degrees of freedom.
\end{abstract}

Id. at 1492-93. For purposes of this discussion, it is only fundamental to note that Professor Vermeule has committed serious consideration to the concept of traditionalism in constitutional interpretation. This project treats traditionalism in its broadest form, and does not depend for its analysis or conclusions on any specific permutation of traditionalism.

${ }^{68}$ Id. at $1502-13$.

${ }^{69}$ Eskridge, supra note 5 .

${ }^{70} I d$. at 194 ("Tradition shall be examined as evidence of original meaning, constitutional adverse possession, and precepts conformed by democratic deliberation.”).

${ }^{71} \mathrm{Id}$. ("That tradition is evolving creates risks of anachronism ... . That tradition is multifarious creates risks of cherry-picking .... That tradition is complicated creates risks of illegitimacy ....").

${ }^{72} \mathrm{Id}$. at 211. Eskridge's reference to legislatures' use of traditionalism reminds us that courts are not the sole expositors of constitutional meaning. At the federal level alone, the three constitutionallyprescribed branches of government-as well as administrative agencies-regularly interpret the Constitution. See generally Barry Friedman, Dialogue and Judicial Review, 91 Mich. L. REV. 577, 580 (1993) ("[T]he everyday process of constitutional interpretation integrates all three branches of government: executive, legislative, and judicial."); Gillian Metzger, Ordinary Administrative Law as Constitutional Common Law, 110 ColUM. L. REv. 479, 500 (2010) (discussing "the important role that 
constitutional traditionalism enrich the Court's "constitutional common law,",73 argues Eskridge, but it provides a coherent means of reconciling some of the Court's more controversial decisions regarding unenumerated rights. ${ }^{74}$ Finally, Steven Calabresi challenged the virtues of traditionalism on its own terms, using the phenomenon of the Supreme Court's overruling of its own precedents since 1937 to argue that traditionalism is inconsistent with the American constitutional "tradition" of relying on "constitutional text and first principles," rather than precedent, to resolve important constitutional questions. ${ }^{75}$

The prominence and volume of scholarly activity dealing with traditionalism since the inception of the Roberts Court demonstrates traditionalism's ongoing importance to discussions about constitutional theory and adjudication. The fact that many current commentators are critical of traditionalism does not belie its relevance. On the contrary, it draws forth the apparent assumption that, despite controversy over traditionalism's theoretical grounding, it remains a sufficiently vital part of constitutional law and practice that it merits continued scholarly treatment. This study is designed to flesh out that assumption by seeking to catalog every instance during its first five terms in which the Roberts Court relied on traditionalist reasoning to interpret a constitutional provision. It not only sheds light on the actual practices of the current and recent Justices, but provides heretofore unavailable insight into Supreme Court reasoning and decision-making that, in turn, informs the way we think about constitutional interpretation.

\section{EMPIRICAL METHODOLOGY}

The empirical goal of this project is to identify and code for every instance in which a majority of the members of the Roberts Court employed traditionalism to interpret a constitutional provision. ${ }^{76}$ Only analyses of specific constitutional

\footnotetext{
administrative agencies play in ensuring that constitutional requirements are met"). For present purposes, however, judicial reliance on tradition is the focus, if for no other reason than a project of this sort depends on the type of written articulation of constitutional reasoning that is common in judicial opinions and far less easily identified with regard to other constitutional actors.

${ }^{73}$ Eskridge, supra note 69, at 212.

${ }^{74}$ Id. at $212-17$.

${ }^{75}$ Steven Calabresi, Tradition of the Written Constitution: Text, Precedent, and Burke, 57 ALA. L. REV. 635, 638 (2006) ("[Traditionalism] is thus a doctrine at war with itself. In this country, our tradition and conventional practice is to revert to constitutional text and first principles on important matters and not to follow precedent.").

${ }^{76}$ In addition to majority opinions of the Court, data was collected on plurality opinions that include a "Judgment of the Court" as well as on concurrences and dissents that include their own Lawyer's Edition Headnotes. See discussion infra note 111 and accompanying text (explaining why data
} 
provisions were included in the dataset; those rare instances where discussions of constitutional principles such as federalism or the separation of powers were undertaken without reference to a specific textual provision embodying those principles were not. ${ }^{77}$ The data is not limited, however, to instances in which traditionalism was used in support of the Court's final conclusion. It includes every instance where traditionalist reasoning was taken up - positively or negatively-by the authoring Justice. The purpose of this broad approach is to better capture the relevance of traditionalism in the Roberts Court's jurisprudence, a task that requires consideration of every instance in which the Court thought enough of traditionalism to include it in its analysis. ${ }^{78}$

The relevant time period for the project is the first five years of the Roberts Court's tenure, from October 2005 through October 2010. The "universe" of

pertaining to concurrences and dissents were ultimately not counted in the preliminary analysis of the positive indicators of traditionalism).

${ }^{77}$ In general, explicit references to non-textual constitutional principles were rarely made without some mention of a constitutional provision, such as the vesting clause of Article II in the case of questions involving the overlap of executive power with that of some other branch of government, see, e.g., Free Enter. Fund v. Pub. Co. Accounting Oversight Bd., 130 S. Ct. 3138, 3151-52 (2010) (“[T]he executive power included a power to oversee executive officers through removal; because that traditional executive power was not "expressly taken away, it remained with the President." (citations omitted)), or the relationship between state action and an enumerated power of Congress in cases implicating principles of federalism. See, e.g., Dep't of Revenue v. Davis, 553 U.S. 328, 342 (2008) (sustaining a state income tax on interest from out-of-state municipal bonds against challenge that it unconstitutionally interfered with federal authority under the Commerce Clause on the basis that the "century-old taxing practice" employed by the state was a "traditional government function").

Moreover, the decision to limit the analysis to constitutional provisions rather than principles was driven by concerns of efficiency as well as accuracy. The goal of this project was to create a database that accurately reflects certain features of Supreme Court opinions, namely those that indicate the presence of a traditionalist methodology in constitutional cases. Any process for identifying judicial references to abstract constitutional principles is, in and of itself, highly subjective and problematic. That process is rendered even more so in the absence of any reference to a specific portion of the constitutional text, especially in those instances (far more common than the alternative) in which a constitutional principle was not expressly referenced by the authoring Justice but was instead inferable from the overall context or tenor of the analysis. As a result of the increased difficulty and subjectivity involved in attempting to identify cases where constitutional principles were employed without any textual references, such references were excluded from the database.

${ }^{78}$ This approach also helps account (indirectly) for the application of traditionalism in concurring or dissenting opinions that the collection of purely affirmative data would not, see discussion infra note 111 and accompanying text, because negative treatment of traditionalism by a majority or plurality of the Court is often a response to the affirmative use of traditionalism in another Justice's secondary opinion in the case. See, e.g., Stop the Beach Renourishment, Inc. v. Fla. Dep't of Envtl. Prot., $130 \mathrm{~S}$. Ct. 2592, 2606 (2010) (addressing Justice Kennedy's argument in his concurring opinion that there is a "common-law tradition" counseling against application of the Takings Clause to judicial action). 
relevant cases is a collection of Supreme Court decisions that is designed to be narrow enough to target cases containing features of interest, but broad enough to ensure identification of the overwhelming majority (if not all) of those cases. The result is an intentionally overbroad initial case list from which the specific cases and opinions of interest are identified through application of a more detailed coding procedure.

With that goal in mind, the universe of relevant cases was identified by performing a LEXIS search of all Supreme Court decisions during the relevant time period-from October 1, 2005 through October 1, 2010-that contain the term "constitution" and at least one of the following tradition-related terms: "tradition," "culture," "custom," "heritage," or "history.,"79 The term "tradition" was included for the obvious reason of identifying instances in which the authoring Justice was explicitly referring to the concept of tradition. "Culture," "custom," and "heritage" were chosen because they are commonly identified as synonyms of tradition. ${ }^{80}$ "History," although not similarly understood as a close synonym of "tradition," was included in the search because it is commonly associated with traditionalism in the constitutional interpretation literature and in the Court's constitutional rhetoric. ${ }^{82}$ The four tradition-related search terms other than "tradition"-_culture," "custom," "heritage," and "history"-were included to prevent under-inclusiveness in the data by recognizing that an author seeking to invoke the concept of tradition may use a term other than "tradition" itself in applying the concept.

The universe of relevant cases included 222 entries for further analysis. The 222 cases were further subdivided into their individual opinions. Sixty-nine

\footnotetext{
${ }^{79}$ Each search term was defined as including the root term and every relevant permutation thereof; for example, the term "constitution" was defined within the search parameters to also include the words "constitutionality" and "constitutionally," and "tradition" included the terms "traditional" and "traditionally," among others.

${ }^{80}$ See Tradition, THESAURus.COM, http://thesaurus.com/browse/tradition (last visited Aug. 20, 2011) (including "custom," "culture," and "heritage" among the list of synonyms for the main entry of "tradition," which was defined as an "established practice"). For a discussion of the number of instances in which these three synonyms of "tradition" were independently instrumental in identifying traditionalism, see discussion infra notes 128-29 and accompanying text.

${ }^{81}$ History is a significantly broader concept than tradition in that history does not require that past events be transmitted to, or authoritative in, the present. See Krygier, supra note 14, at 240 (defining a tradition as requiring that past events have an "authoritative presence" and that they "have been ... passed down over intervening generations"). Some of the consequences of history's broader definition are addressed in the methodological protections against overbreadth described infra Part III.C.

${ }^{82}$ See, e.g., Baker, supra note 30 (describing the use of "history and tradition" as an independent interpretive method).
} 
variables were considered for every opinion containing the terms "constitution" and at least one of the tradition-related search terms. Information was collected with at least two specific goals in mind: first, to ensure that the data ultimately collected was accurate, reliable, and reproducible; and second, to generate a database that would provide the quantity and type of information that current and future scholars would find helpful in evaluating the use of traditionalism by the Roberts Court.

\section{A. Data Collection}

In order to achieve the first goal of accuracy and reliability in the data, a code book was drafted with instructions for how each individual piece of information in the dataset (entry) was to be gathered and recorded ("coded") by the individuals responsible for data collection (the "coders"). ${ }^{83}$ There were always precisely four coders working on the project at any one time. As this coding process developed, the code book was periodically updated to reflect the best practices gleaned from experience with and study of the collected data. ${ }^{84}$ Many of the coded entries consisted of easily verifiable information (such as case citations) that required little or no judgment or interpretation on the part of the coders. ${ }^{85}$ Nevertheless, each judicial opinion was coded in its entirety by two different coders to increase accuracy. After each opinion was coded in duplicate, a comparison was performed of the data points from each of the two coders and any discrepancies highlighted for reconciliation by a third party. These discrepancies were infrequent and, in almost all instances, the product of simple human error.

Data entries that require a greater degree of coder judgment or interpretation, such as information about whether an occurrence of a tradition-related search term reflects an instance of traditionalist reasoning (the "Const Analysis" variable), ${ }^{86}$

${ }^{83}$ See code book (on file with author).

84 This iterative approach is common in content analysis. See KLAUS KRIPPENDORF, CONTENT ANALYSIS 361 (2d ed. 2004) ("It is not unusual for a content analysis to need several iterations of locating unreliabilities, correcting their causes, and repeating these steps until applicable standards are satisfied. This is especially true in the development of coding/recording instructions.").

${ }^{85}$ A full explanation of the data points collected for each judicial opinion and the varying degrees of coder judgment and interpretation required for each is discussed infra Part III.B.

${ }^{86}$ There is no formal distinction in the code book between entries that require coder judgment and those that do not. In fact, all coding activities require at least some coder judgment, even in the most straightforward instances such as determining which case citation is attributable to the United States Reports as opposed to the Supreme Court Reporter, LEXIS, or Westlaw. Notwithstanding the fact that a modicum of judgment is inherent in every coding decision, review of the Code Book shows that some variables require coders to read sources such as the headnotes provided by the editors of the Lawyer's Edition of the United States Supreme Court Reports to determine if a headnote (1) describes a legal analysis of a constitutional provision (the "Const Analysis" variable), and if so (2) which constitutional 
raise questions not only of accuracy - a subject that will be addressed in the next section regarding the data itself ${ }^{87}$ - but of reliability, namely whether the results reached by individual coders can be reproduced by someone of comparable skill in the field following the same set of instructions. ${ }^{88}$ In order to address the reliability question, specific reliability tests were run in which the coders were asked to provide entries for data points that required individual judgment by relying only on the instructions provided in the code book. ${ }^{89}$ For those data points that require coder judgment, agreement rates were measured based on the percentage of opinions in which all four coders unanimously agreed on the proper entry for that opinion. 90 For the "Const Analysis" and "Frequency" variables, all four coders were unanimous between 88 and $92 \%$ of the time, ${ }^{91}$ and with regard to the "Const

provision is being analyzed in the portion of the opinion described by that headnote (the "Const Prov") variable). Because coders are more likely to reach different conclusions in coding for these variables than for more objective ones like case citation, steps were taken to quantify the degree of coder agreement with regard to those variables that required greater individual judgment.

87 See discussion infra notes 130-42 and accompanying text (discussing how the dataset avoids problems of under- or over-inclusiveness by promoting transparency in the data).

${ }^{88}$ See KRIPPENDORF, supra note 84, at 18 (defining replicability, which is in turn defined as "the most important form of reliability," as when "researchers working at different points in time and perhaps under different circumstances ... get the same results when applying the same technique to the same data").

${ }^{89}$ It should be noted that while reliability could easily have been judged across all variables in the study, including those such as case citation that require no coder judgment and are only reasonably susceptible to human error, coders were not measured independently on their level of agreement regarding purely objective variables such as case citation for fear of skewing the reliability data toward false positives. The question of reliability or accuracy for objective variables was addressed by the duplicate coding process, which not only identified few points of disagreement between coders, but also worked to ameliorate the potential for human error by subjecting disagreements to additional review by a third party, in this case the author.

${ }^{90}$ Unanimity is not a prerequisite for obtaining a measure of reliability, but was used here because focusing only on incidents where all four coders reached the same result is a more conservative way to measure reliability. As such, the positive reliability results utilizing a unanimity model are strong evidence that the methodology employed is reproducible.

${ }^{91}$ For the "Const Analysis" variable, the additional step was taken of calculating a kappa coefficient. The kappa coefficient is "one of the most widely-used agreement coefficients among researchers." Kilem L. GWeT, HANDBOOK OF INTER-RATER RELIABILITY 2 (2d ed. 2010). The results of the reliability test yielded a kappa value of 0.929 for the "Const Analysis" variable. See id. at 26-28 (explaining how to calculate inter-rater reliability for multiple coders). While there is no firm standard for determining the strength of coder reliability based on a kappa value, Landis and Koch suggest that kappa values between 0.0 and 0.20 are poor, between 0.21 and 0.40 are fair, between 0.41 and 0.60 are moderate, between 0.61 and 0.80 are substantial, and values greater than 0.81 are near perfect. J. Richard Landis \& Gary G. Koch, The Measurement of Observer Agreement for Categorical Data, 33 
Prov" variable, the four coders were unanimous $94 \%$ of the time..$^{2}$ These results indicate a high degree of reliability in the data, even under the most conservative estimates. $^{93}$

\section{B. The Dataset}

The collected data represents four categories of information: information about (1) the case, (2) the authoring Justice, (3) the opinion, and (4) other information of interest. ${ }^{94}$ The first category, case-related information, includes two identifying numbers unique to the dataset, the case name, four different case citations, the dates of decision and oral argument for the case, and the "Decision Type." The "Decision Type" variable is based in part on a similar variable in Professor Spaeth's Supreme Court Database (SCD) ${ }^{95}$ and is used to define which among the various kinds of decisions rendered by the Court are to be part of the dataset. Only orally argued cases resulting in a formal written opinion and decrees from the Court qualify. This includes per curiam and plurality opinions in cases involving oral argument but not memorandum decisions or denials of certiorari. ${ }^{96}$ One reason for focusing only on orally argued, formal written opinions is the lack of information relevant to this study in other types of opinions. Moreover, memorandum decisions and opinions relating to denials of certiorari rarely include either a full exposition of the reasoning behind the Court's decision or, in the case of certiorari denials, the participation of the entire Court. Thus, in the interest of developing a dataset that is internally consistent and most likely to offer the desired information, only formal opinions in orally argued cases were considered.

Cases with Decision Types that qualify them for additional consideration were reviewed on an opinion-by-opinion basis. Only opinions containing at least one of the tradition-related search terms were reviewed. Among the information collected for each of these opinions was the name of the authoring Justice, the

BIOMETRICS 159 (1977). Based on this standard, a kappa score of 0.9294 for the "Const Analysis" variable indicates a near perfect degree of reliability.

${ }^{92}$ Because the "Const Prov" variable does not include categorical data, a kappa value was not calculated in the same way as for the "Const Analysis" variable. See supra note 91.

${ }^{93}$ See supra notes 89-90 (describing the conservative approach employed in measuring and reporting reliability).

${ }^{94}$ A template of the spreadsheet into which the data was recorded is reproduced as Exhibit 1.

${ }^{95}$ See The SuPreme CourT DatABASE, http://scdb.wustl.edu/data.php (last visited Aug. 20, 2011).

${ }^{96}$ Any decision types not meant to be included in the dataset are coded as having a "Decision Type" of "other" and are not the subject of any additional coding. 
U N I V E R S I T Y OF P I T T S B U R G H L A W R E V I E W

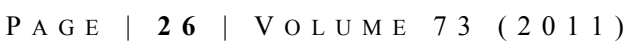

political party of the President that nominated that Justice, the partisan composition of the Senate that confirmed that Justice, and the final tally of the Justice's Senate confirmation vote. The political party of the nominating President as well as the party composition and vote tally were included as potential indicators of the political affiliation of the Justice, which may in turn be useful in investigating a correlation between political ideology and traditionalism.

Information about the opinion's authoring Justice is accompanied by the largest category of information in the dataset: information about the content of the opinion itself. Among the information of interest in this category is the type of opinion being considered (majority, plurality, concurrence, dissent, etc.) and the number and names of the Justices that signed onto the opinion as non-authors. Most important, however, is the data associated with the question of whether the authoring Justice employed a traditionalist constitutional analysis in his or her opinion and, if so, which constitutional provision was the subject of that analysis. A variety of different information was collected in relation to this question, all of which is designed to create a largely objective framework for addressing what is, at bottom, a subjective decision by the author as to whether to employ constitutional traditionalism.

Traditionalist constitutional analyses were identified by considering each occurrence of the five tradition-related terms - "tradition," "culture," "custom," "heritage," and "history"-in every opinion within the universe of relevant cases. The data collection process was identical for all five terms. The number of times that each tradition-related term appears in an opinion was recorded. Each occurrence of that term was then examined to see if it appears in a portion of the opinion described by at least one of the Headnotes provided by the publishers of the Lawyer's Edition of the United States Supreme Court Reports ('Lawyer's Edition Headnotes" or "Headnotes"). ${ }^{97}$ Where the tradition-related term appears under a Lawyer's Edition Headnote, ${ }^{98}$ and that Headnote describes an analysis of a specific constitutional provision, then the opinion was treated as one incorporating

\footnotetext{
${ }^{97}$ Only the Headnotes prior and closest to the occurrence of the tradition-related term were included in the analysis.

${ }^{98}$ In many cases, more than one Headnote is assigned to a single portion of an opinion containing one of the tradition-related terms. In such instances, all of the applicable Headnotes were reviewed, and if any of those Headnotes indicated that a constitutional analysis is being undertaken within that portion of the opinion, the opinion was coded as incorporating traditionalism.
} 
a positive indicator for traditionalism with respect to that constitutional provision. ${ }^{99}$ This approach has procedural and substantive advantages. Procedurally, it is relatively objective in its application. The presence of certain terms and the substance of Lawyer's Edition Headnotes under which they occur are not terribly controversial propositions. ${ }^{100}$ Substantively, it provides core indicators of admittedly elusive information about a Justice's theoretical approach to a constitutional problem. The presence of a tradition-related term - and especially the term "tradition" itself-is, at minimum, evidence that the concept of tradition is relevant to that portion of an opinion. A description by the applicable Lawyer's Edition Headnotes of a constitutional analysis suggests a connection between the concept of tradition and a constitutional issue. Once this initial connection was identified, questions of under- and over-inclusiveness were addressed by incorporating additional data points as well as structural mechanisms in the design of the study to better focus the results. ${ }^{101}$ Although they would otherwise have been coded affirmatively, opinions in which a tradition-related search term was used to describe only the Court's use of its own precedent-for instance by reference to the Court's "traditional interpretation of the Sixth Amendment right to counsel"-were

${ }^{99}$ In the interest of convenience, opinions containing positive indicators of traditionalism will be referred to interchangeably throughout the remainder of this paper as opinions including examples of traditionalism or traditionalist analyses.

The presence of a positive indicator of traditionalism was coded under the variable "Const Analysis T." The variable name "Const Analysis T" is specific to an analysis of the term "tradition." Although precisely the same analysis is performed under "Const Analysis T" for all five traditionrelated terms, the variable names change slightly for each term. For the terms "culture," "custom," "heritage" and "history," the analogous variable names are "Const Analysis Custom," "Const Analysis Culture," "Const Analysis Heritage," and "Const Analysis Hist," respectively.

The specific constitutional provision(s) mentioned in the Headnote were coded separately under the variable "Const Prov T." Specific constitutional provisions are coded here using the same numerical codes assigned to them by the Supreme Court Database Code Book. See Harold SpAETH ET AL., THE SuPreme COURT DatABASE CODE BOOK, at A19, http://scdb.wustl.edu/_brickFiles/2011_01/SCDB_ 2011_01_codebook.pdf (last visited Aug. 20, 2011). The variable name "Const Prov T" is specific to an analysis of the term "tradition." Although precisely the same analysis that is performed under "Const Prov T" is performed for all five tradition-related terms, the variable names change slightly for each term. For the terms "culture," "custom," "heritage" and "history," the analogous variable names are "Const Prov Custom," "Const Prov Culture," "Const Prov Heritage," and "Const Prov Hist," respectively.

${ }^{100}$ This is confirmed in the calculation of a kappa coefficient for the "Const Analysis" variable. See supra note 91.

${ }^{101}$ For a thorough description of how potential problems of under- and over-inclusiveness were addressed, see infra Part III.B. 
not coded as traditionalist. ${ }^{102}$ There are at least three reasons for this decision. First, in the context of Supreme Court decisions, the relevant traditions under stare decisis - the lines of cases or doctrinal history relating to a particular issue - have little if any democratic or social pedigree. They are internal to the Court itself; they do not exhibit any of the fundamental elements of tradition with regard to any community outside of the Court. ${ }^{103}$ In some instances, lines of precedent may even be in conflict with those broader traditions. ${ }^{104}$ This is an important distinction from other modes of traditionalism, which seek to shape legal and political change through reliance on the collective and lasting wisdom of the community at large. ${ }^{105}$ Therefore, while still generally traditionalist, precedential reasoning by the Supreme Court is significantly limited in its source material in a way that other forms of traditionalism are not.

A second important, and related, difference between stare decisis and other modes of traditionalism is stare decisis' purely procedural use of tradition. Although the Court's choice to rely on precedent may profoundly impact its

${ }^{102}$ Rothgery v. Gillespie County, 554 U.S. 191, 209 (2008).

${ }^{103}$ It is important to note that the use of precedent by the Court is meant in the narrowest sense. It does not include the Court's reliance on, for example, common law doctrines that have an independent traditional, jurisprudential pedigree outside of their role in a previous Supreme Court decision. See discussion supra note 55 and accompanying text (discussing the role of common law traditions in constitutional traditionalism). While lines of Supreme Court precedent will certainly overlap with concepts that derive from independent sources of tradition such as the common law, the mere fact of that overlap does not exclude a reference to those independent sources of tradition from being coded as an example of traditionalism. Furthermore, traditions that have developed as a result of Supreme Court decisions into broader legal, political, social, or cultural phenomena-such as the use of Miranda warnings - are not treated merely as products of stare decisis, but as substantive traditions that include a broader community than merely the Court (at least the entire law enforcement community, for example, in the Miranda context). Cases invoking such traditions are thus included in the database where they otherwise qualify as positive indicators of traditionalism. Opinions are only excluded from the database where the sole reason for invoking tradition was to refer to the use of Supreme Court precedent qua Supreme Court precedent.

${ }^{104}$ See David A. Strauss, Tradition, Precedent, and Justice Scalia, 12 CARDozo L. Rev. 1699, 1706 (1991) ("Some precedents may be said to be part of a tradition. But not all are. Some are simply the decisions of a group of judges rendered a few years ago.").

${ }^{105}$ See BURKE, supra note 4, at 59 ("'I]ndividuals would do better to avail themselves of the general bank and capital of nations and of ages ...."). Even the longest-lasting precedential traditions in American constitutional law reflect at best the "collective" wisdom of only a handful of Justices; a set of traditions, for sure, but one that is markedly different from the broader political and social practices that traditionalism relies on to directly inform our understanding of the Due Process Clause, or that traditionally has been part of the general common law, and thus draws on a deeper and broader source of wisdom than that provided by the 113 Justices that have served on the Supreme Court during its 220 year history. 
resolution of a constitutional question, the only necessarily traditionalist feature of precedential reasoning is its focus on previous Supreme Court decisions to justify a result. If a line of precedent does not employ the concept of tradition in its substantive constitutional analysis, stare decisis does nothing more to bring the concept of tradition to bear. This is distinct from the other examples of traditionalism offered here, ${ }^{106}$ which look to traditions to provide substantive content to constitutional text and doctrine.

The third reason for excluding stare decisis from this project's definition of traditionalism is a more practical one. While this definition may functionally overlook examples of common law constitutionalism, which is fairly described as a potential subset (albeit a distinct one) of traditionalism, ${ }^{107}$ it does so in the interest of preserving clear boundaries around the modes of traditionalism targeted by this study. The Court could refer to its use of precedent in a constitutional analysis in a seemingly infinite number of ways. In addition to references to its own traditions or historical practices, citations to case names are a positive indicator of precedential reasoning, thereby making it effectively impossible to reliably and accurately capture examples of the Court's use of its own traditions or precedent through the type of textual analysis employed here. Thus, due to the unique concept of tradition employed in stare decisis, as well as the ostensibly limitless ways in which a reliance on precedent could be articulated by an authoring Justice, instances in which the Court invoked tradition solely to articulate reliance on its own precedent were not coded as traditionalist.

In addition to the presence of a tradition-related term in a constitutional analysis, the constitutional provision at issue ${ }^{108}$ the frequency with which a tradition-related term is used in that constitutional analysis, ${ }^{109}$ and the number and names of the Justices that signed onto that analysis were recorded for each term in

\footnotetext{
${ }^{106}$ See supra Part II.B (describing different formulations of traditionalism).

${ }^{107}$ See supra notes 56-58 and accompanying text (describing traditionalism as including the traditions of the common law, including reliance on precedent); Strauss, supra note 4, at 879 ("The common law tradition rejects the notion that law must be derived from some authoritative source and finds it instead in understandings that evolve over time. And it is the common law approach . . . that best explains, and best justifies, American constitutional law today.").

${ }^{108}$ In cases where the applicable Headnotes describe analyses of multiple constitutional provisions, all of those provisions were recorded in connection with that opinion.

109 "Used as part of a constitutional analysis" is shorthand for instances when a tradition-related search term occurs under a Headnote depicting a constitutional analysis. See supra notes 97-99 and accompanying text.
} 
each opinion. ${ }^{110}$ If the applicable Headnote did not describe a constitutional analysis, then the opinion was coded as not incorporating traditionalism. If an opinion containing any of the tradition-related terms simply did not contain any Lawyer's Edition Headnotes, or if all of the tradition-related terms in the opinion occurred prior to the first Headnote in that opinion, the opinion was coded as not having any applicable Headnotes. ${ }^{111}$ Because opinions coded as lacking Headnotes cannot, by definition, include a positive indicator of traditionalism, ${ }^{112}$ those too were treated as not incorporating a traditionalist analysis. ${ }^{113}$

Finally, in order to provide a more accurate and transparent depiction of how these terms are used by the authoring Justice, every opinion that contains a tradition-related term in a constitutional analysis also includes a code for the "Mode" and "Type" of that usage. In this instance, the "Mode" of usage is the grammatical context in which the authoring Justice uses the term. ${ }^{114}$

\footnotetext{
${ }^{110}$ Where a different collection of Justices signed onto the specific section of an opinion containing a positive indicator of traditionalism, only those Justices' names were included in the dataset.

${ }^{111}$ Majority opinions or, in the absence of a majority, plurality opinions announcing the judgment of the Court in a given case include Lawyer's Edition Headnotes. Therefore, the project's focus on majority and plurality opinions renders any concerns about the lack of Headnotes essentially moot. Conversely, since the overwhelming majority $(96.8 \%)$ of concurrences and dissents containing tradition-related terms in the universe of relevant cases do not include Headnotes, they are coded accordingly. In fact, it is partially for this reason that the project focuses on majority and plurality opinions in orally argued opinions, rather than on every opinion in every case, as only the former contain Headnotes reliably and thoroughly enough to be amenable to the instant methodology.
}

Although not expressly excluded as a possibility by the choice of opinions to be coded, very few of the cases coded for the Roberts Court included tradition-related search terms prior to the occurrence of the opinion's first Headnote, and none of these instances led to an under-inclusive result. That is, none resulted in an opinion being wrongly characterized as not involving traditionalism. See infra notes 128-32 and accompanying text (discussing provisions taken to avoid under-inclusive results in the dataset).

${ }^{112}$ A positive indicator of traditionalism for purposes of this study is defined supra at notes $97-99$ and accompanying text.

${ }^{113}$ Opinions without applicable Headnotes were, however, coded somewhat differently than opinions that included applicable but non-constitutional Headnotes. The former were coded as a separate category of "opinions without Headnotes," rather than as opinions that did not include a substantive traditionalist analysis. This separate category of "opinions without Headnotes" was created because the methodology of the study does not allow for any more detailed account of the content of those opinions. See supra notes 97-99 and accompanying text (describing how an opinion is designated as including traditionalism).

${ }^{114}$ Distinctions are drawn between tradition-related terms appearing in the body of the author's own original text, as part of cited quotations, in parentheticals describing cited authority, or in any of these forms within a footnote. Where a single term occurs multiple times and in multiple modes, each mode that is represented in the opinion is coded separately, and the number of occurrences of the relevant term 
The "Type" variable records modifying language meant to elaborate on the type or source of tradition employed in the analysis. Such modifying language was included in the dataset when it appeared in the same sentence as the term and operated either as an adjective directly modifying the tradition-related term (e.g., "common law tradition") ${ }^{115}$ or as a prepositional phrase describing the nature of the tradition being referred to (e.g., "traditions of our society"). ${ }^{116}$ Any language meeting these criteria was recorded verbatim. This was useful not only to identify instances where a tradition-related term may have been employed for some nonconstitutional purpose, ${ }^{117}$ but also to provide additional insight into the specific sources and concepts of tradition that the Justices deem persuasive to constitutional meaning.

There is one opinion-related variable that applies only to the term "tradition" and not to any of the other four tradition-related terms. The "Traditional State Function" variable identifies a distinct form of traditionalist argument that is most frequently seen in the Court's federalism cases. ${ }^{118}$ The argument considers whether an activity is part of a traditional state (as opposed to federal) governmental function as a basis for limiting federal power. Only explicit references by the Court to concepts such as "traditional governmental functions"119 or "areas of traditional

that were used in that mode are indicated parenthetically. For example, where an opinion includes five instances of a specific tradition-related term being used as part of a constitutional analysis, such that three occurrences appeared in the author's original text in the body of the opinion (a mode of "1") and the other two occurrences were part of a cited quotation in a footnote (a mode of " 4 "), the mode variable for that term would read "1(3), 4(2)."

Where a tradition-related term is plainly unconnected to the constitutional analysis described in the applicable Headnote, such as when it appears in the title of a cited article or book or in the name of a public building, it is coded as having a mode of "other." See, e.g., Davis v. Washington, 547 U.S. 813, 830 n.5 (2006) (using the term "history" in a citation to L. FRIEDMAN, CRIME AND PUNISHMENT IN AMERICAN History 67-68 (1993)); Skilling v. United States, 130 S. Ct. 2896, 2914 n.12 (2010) ("history" only occurred in the name of the American Museum of Natural History).

115 See Melendez-Diaz v. Massachusetts, 129 S. Ct. 2527, 2534 (2009) (considering “common law tradition" of live testimony in court as part of an analysis under the Sixth Amendment).

${ }^{116}$ See Virginia v. Moore, 553 U.S. 164, 171 (2008).

${ }^{117}$ For a thorough discussion of how the "Type" variable is used to limit this brand of over-inclusiveness in the dataset, see infra note 139 and accompanying text.

${ }^{118}$ See Lynn A. Baker, Lochner's Legacy for Modern Federalism: Pierce County v. Guillen as a Case Study, 85 B.U. L. REV. 727 (2005) (reconciling three Rehnquist-era federalism cases through their reliance on the traditional state function doctrine); but see Larry Yackle, Lochner: Another Time, Another Place, 85 B.U. L. REV. 765 (2005) (arguing that Professor Baker overstated the role of the traditional state function test in the federalism context).

${ }^{119}$ Garcia v. San Antonio Metro. Transit Auth., 469 U.S. 528 (1985). 
U N I V E R S I T Y O F P I T T S B U R G H L A W R E V I E W

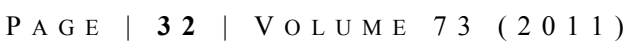

state regulation," were recorded as evidence of the traditional state function rationale. $^{120}$

There are two opinion-related variables that only apply to occurrences of the term "history." The "Originalism" and "Originalism Frequency" variables code for instances where the term "history" is used in reference to the originating history of a constitutional provision. References to the historical origins of the provision must be explicit (e.g., a reference to "the history of the adoption of the [Tonnage] Clause") ${ }^{121}$ to be treated as a positive indicator for originalism. The "Originalism Frequency" variable records the number of instances in a given opinion where the term "history" was used as a positive indicator of an originalist analysis.

The last category of information collected from the universe of relevant cases could also be described as case-related information. This category is treated separately because, unlike the case-related information described above, the variables in this category are only coded for in those instances where an opinion has already been identified as traditionalist. There are four variables in this category. The first is entitled "Remedy" and asks whether the non-governmental party in the case obtained any relief whatsoever from the Supreme Court's decision. $^{122}$ This information will be particularly relevant in criminal and civil rights cases where the constitutional balance between governmental power and individual rights is critical. ${ }^{123}$ The second variable, "Public Interest," seeks to describe the social and political significance of the case. This is done by recording whether the Solicitor General (SG) participated as an amicus, as well as the number of amicus briefs filed by parties other than the SG. The code for this variable creates a scale of public importance based on whether more than the average

\footnotetext{
${ }^{120}$ United States v. Morrison, 529 U.S. 598, 615 (2000).

${ }^{121}$ Polar Tankers, Inc. v. City of Valdez, Alaska, 129 S. Ct. 2277, 2283 (2009).

${ }^{122}$ Relief is defined broadly to include a procedural victory or a remand to the appellate court to reconsider a disputed issue that had previously gone against the non-governmental party. Similar data points were collected as part of an empirical study by Cass Sunstein and others designed to evaluate the influence of political ideology on judicial decision-making in federal courts of appeals. See Cass R. Sunstein et al., Ideological Voting on Federal Courts of Appeals: A Preliminary Investigation, 90 VA. L. REV. 301 (2004).

${ }^{123}$ Where a case involves either two private or two governmental parties, this variable is not applicable to the analysis, and is coded accordingly.
} 
number of amicus briefs were filed in the case, ${ }^{124}$ and whether the Court or the SG felt that the case merited the SG's involvement.

The third and fourth variables in this category are identical to variables in the SCD. The "Issue" variable describes the subject matter of the controversy before the Court. ${ }^{125}$ Due to its highly subjective nature, ${ }^{126}$ this project did not endeavor to recreate the "Issue" variable employed in the SCD but instead simply imported it; for every case in which the SCD contained an entry under the "Issue" variable, the same entry was recorded for that case in the dataset. ${ }^{127}$ The "lawSupp" variable from the SCD identifies the legal provision(s) at issue in the case. It is imported into the current database to provide a check against the constitutional provision data recorded for traditionalist opinions as well as the potential under- or overinclusiveness of the traditionalism determinations themselves.

\section{Under-and Over-Inclusiveness}

An ongoing concern in the project's data collection phase has been to protect against under- or over-inclusive results regarding the Roberts Court's use of traditionalism in constitutional cases. A number of steps were taken to avoid each of these problems. Under-inclusiveness results where an opinion includes a traditionalist analysis but is not coded as such in the dataset. There are generally two scenarios under the instant data collection process where an under-inclusive result could occur. The first is an opinion that invokes constitutional traditionalism but does not contain either the word "constitution" or any of the tradition-related search terms. The primary safeguard employed against this difficulty is the use of multiple search terms. Since some permutation of the word "constitution" is almost certain to appear at least once in every case involving the interpretation of a constitutional provision, ${ }^{128}$ a far more realistic way for an opinion employing

124 Paul M. Collins, Jr., Friends of the Supreme Court: Interest Groups And Judicial DECISION MAKING (2008) (citing the average number of amicus briefs filed per case during the period from 1946-2001 as 2.26).

${ }^{125}$ For example, Supreme Court Database (SCD) entries under the "Issue" variable that were imported into the dataset include "habeas corpus" (10020), "desegregation, schools" (20050), and "search and seizure (other than as pertains to vehicles or Crime Control Act)" (10050). SPAETH ET AL., supra note 99, at A13.

${ }^{126}$ See id. (describing the content of the "Issue" variable).

${ }^{127}$ Because the "Issue" variable is completely derivative, however, it is not included for those cases in which the SCD failed to include it, resulting in incomplete "Issue" data for the decisions of the Roberts Court.

${ }^{128}$ This is especially true in light of the presence of both LEXIS and Lawyer's Edition Headnotes in opinions searchable by the LEXIS database. Each Headnote includes a topical heading or headings that 
traditionalism to be overlooked by the instant coding protocol is through the complete absence of any of the tradition-related search terms in that opinion. This, too, is highly unlikely due to the sheer number of synonyms of "tradition" employed in the search, especially in light of the fact that three of the terms used"culture," "custom," and "heritage" - are close synonyms of "tradition" but appear significantly less often in cases including the word "constitution" than the other two search terms, "tradition" and "history." Moreover, occurrences of the terms "culture," "custom," and "heritage" only lead to positive results in thirteen out of 222 cases $(5.8 \%)$ and only occur in one case in which "tradition" or "history" are not also positive indicators. ${ }^{129}$ The diminishing returns on close synonyms like "culture," "custom," and "heritage" indicate that additional, more attenuated terms are even less likely to be positive indicators of traditionalism and would therefore provide little, if any, additional benefit toward preventing under-inclusive results.

The second scenario that could lead to the dataset being under-inclusive is if an opinion did, in fact, use traditionalism to interpret a constitutional provision, but none of the tradition-related search terms in that opinion occurred under a Lawyer's Edition Headnote identifying a constitutional analysis. This issue is harder to theorize because the Lawyer's Edition Headnote is an additional variable. Whether an instance of traditionalism is overlooked in this scenario depends not only on one of the tradition-related search terms appearing in the opinion, but on the Headnotes in that opinion accurately reflecting its constitutional content. There are a number of responses and steps taken to alleviate this concern. As an initial matter, the Lawyer's Edition Headnotes were chosen over other sources of similar information because they historically have been designed to reflect precisely the information sought in this study - the substantive content of specific portions of an opinionand offer no reason to doubt their effectiveness in this regard. ${ }^{130}$ In addition, the

are meant to categorize the portion of the opinion to which that Headnote refers, as well as commentary within the text of the Headnote. This additional information, beyond the syllabus provided by the Reporter of Decisions and the text of the opinions themselves, makes the already significant likelihood even greater that a case involving a constitutional issue would include some permutation of the term "constitution."

129 See Jones v. Flowers, 547 U.S. 220, 233 (2006) (discussing the importance of notice under the Fourteenth Amendment Due Process Clause even in situations such as those governed by Miranda, where the required notice has "become part of our national culture").

${ }^{130}$ It is worth noting that since approximately the beginning of 2007 , the Lawyer's Edition Headnotes changed their format to mimic those provided by Lexis-Nexis, which around that time acquired the publisher of the Lawyer's Edition. The result is a collection of Lawyer's Edition Headnotes since about 2007 that occur much more frequently throughout an opinion and seek to describe much smaller sections of those opinions than their predecessors, almost always through the use of language taken directly from the opinion itself. While a potentially significant difference, in fact the switch to narrower, 
"lawSupp" variable replicated from the SCD provides useful information to help identify and remedy potential false negatives. A review was conducted of every opinion that includes a tradition-related search term, was coded as not employing constitutional traditionalism, and has a "lawSupp" entry indicating that the case involves the interpretation of a constitutional provision. ${ }^{131}$ Only three of the nineteen opinions meeting this description were potential examples of underinclusiveness, revealing that the likelihood of under-inclusive results under the current coding protocol is small. ${ }^{132}$

more specific Headnotes did not exacerbate the likelihood of under-inclusive results, as evidenced by the fact that only three of the nineteen most likely candidates for under-inclusiveness in the dataset showed any real potential for qualifying as under-inclusive, and even then could have easily been construed as either properly coded or inconsequential in their omission from the positive traditionalism data. See discussion infra note 132 and accompanying text (explaining the three instances of potentially under-inclusive results).

${ }^{131}$ Cases that were entirely devoid of a "lawSupp" entry in the SCD were not counted. Had they been included, the percentage of potentially under-inclusive results would have been even further reduced. Although not the only possible examples of under-inclusive coding, cases that are coded negatively for traditionalism and positively for an important constitutional issue were chosen for further review because they were the best candidates for under-inclusiveness.

132 The three cases are Tenn. Secondary Sch. Athletic Ass'n v. Brentwood Acad., 551 U.S. 291 (2007), Yeager v. United States, 129 S. Ct. 2360 (2009), and Crawford v. Marion Cnty. Election Bd., 553 U.S. 181 (2009). Brentwood involved one occurrence of the term "tradition" in a portion of the opinion prior to the presence of any Headnotes. In a case about the First Amendment implications of an athletic recruiting rule, the term was used as part of a preliminary discussion of the Court's precedents pertaining to First Amendment protections for in-person client solicitation by lawyers. More specifically, it was included as part of a quote from Ohralik v. Ohio State Bar Ass'n, 436 U.S. 447 (1978), which explained that in-person solicitation was not protected in the same manner as "forms of speech more traditionally within the concern of the First Amendment." Id. at 455. Besides the fact that the issue in Brentwood had nothing to do with attorney solicitation of clients, it is instructive that the editors of the Lawyer's Edition did not find the portion of the opinion containing the term "tradition" worthy of a descriptive Headnote - a rare phenomenon in majority and plurality opinions - and that the term does not appear again in the portion of the opinion applying the First Amendment to the issue before the Court.

Yeager involved a single use of the term "history" in a portion of the opinion discussing issue preclusion in criminal cases. Although the relevant Headnote did not contain any language explicitly identifying a constitutional component to the analysis, the opinion involves at least in part an analysis under the Double Jeopardy Clause, and it appears that the discussion of issue preclusion is related to that analysis. Even if Yeager is an example of under-inclusiveness, the relevant term occurred only once in the opinion, indicating that any role played by traditionalism in the Court's reasoning was minor. Crawford involved an Equal Protection Clause analysis of a voter identification provision. The term "history" appeared four times in a portion of the opinion discussing the prevalence of voter fraud, which the Court was considering as part of the substantial state interest segment of the constitutional analysis. The relevant Headnote refers only to the statutory provisions at issue in the case, and as such does not indicate that a constitutional issue is being addressed in the opinion. A closer review of the uses of various permutations of "history" in Crawford, however, reveal that the historical references are at best 
As with under-inclusiveness, over-inclusiveness is also a concern. The dataset is over-inclusive if it mistakenly identifies an opinion as traditionalist. ${ }^{133}$ There are two primary ways in which this can occur. The first is where a tradition-related search term is under a constitutional Headnote but is not part of a constitutional analysis. There are a number of ways this could happen, and thus a variety of protections are built into the data collection process to avoid such an outcome. All of the protections are designed to promote transparency in the reporting of information and, as such, to offer the fullest account of the Court's use of traditionrelated terms without compromising the data's reproducibility. ${ }^{134}$

One of these protective measures is the use of multiple tradition-related search terms. Employing five terms relating to the concept of tradition in the search creates the potential for internal corroboration. Identifying multiple traditionrelated terms as positive indicators of traditionalism creates greater confidence in the accuracy of the positive result than would a positive indication from the occurrence of a single term. ${ }^{135}$ Another (related) measure designed to protect against over-inclusiveness is the coding of the frequency with which a traditionrelated search term acts as a positive indicator of traditionalism. ${ }^{136}$ The greater the

tangential to the constitutional question; they generally refer to the historical presence (or lack thereof) of voter fraud in Indiana and nationally, after which the Court appears to rely little if at all on this historical fact in concluding that "[ $\mathrm{t}]$ here is no question about the legitimacy or importance of the State's interest in counting only the votes of eligible voters." 553 U.S. at 196. The conclusory nature of this statement and its failure to refer even indirectly to the discussion involving the uses of the term indicate that any concerns about Crawford representing an instance of under-inclusiveness in the dataset should not be construed as significant in terms of evaluating the accuracy of the coding of Crawford or of the data in general.

${ }^{133}$ Over-inclusiveness could also be defined more narrowly, to include any instance where a single occurrence of a tradition-related search term was wrongly coded as being part of a traditionalist analysis. While this measure would arguably be the most thorough way to measure the data's accuracy, it extends the accuracy inquiry beyond the natural and relevant boundaries of the inquiry. This project focuses on traditionalism on an opinion-by-opinion basis because that is the natural context in which to evaluate constitutional interpretation. Whereas it is possible to undertake a review of constitutional interpretation on a sentence-by-sentence basis, and this may even be the preferred approach in a study focused on, for example, judicial rhetoric, this more narrow approach adds little if any value to an investigation focused on the jurisprudence of a Court or individual Justice.

${ }^{134}$ For an additional description of how over-inclusiveness was accounted for in the preliminary findings associated with this project, see discussion infra note 143 and accompanying text.

135 Twenty-seven of the sixty-two cases containing positive indicators of traditionalism included multiple tradition-related search terms as positive indicators.

${ }^{136}$ Thirteen of the thirty-five cases containing only a single tradition-related search term as a positive indicator of traditionalism included multiple instances in which that term operated as a positive indicator in the opinion. 
number of positive indicators in a given opinion, the greater the likelihood that the tradition-related term does in fact contribute to a constitutional analysis. ${ }^{137}$

Another protective device that increases transparency and thus protects against over-inclusiveness is the "Mode" variable, which records the grammatical context in which every positive indicator of traditionalism appears in the opinion. ${ }^{138}$ The "Mode" variable prevents over-inclusiveness due to traditionrelated search terms appearing in wholly inapposite contexts, such as the titles of publications or the names of organizations, and in more obscure portions of an opinion, such as parentheticals to citations. A more subtle and qualitative way to protect against over-inclusiveness is the use of the "Type" variable, which is useful not only to provide more detailed information about the specific concepts of tradition employed by the Court, but to protect against positive results based on tradition-related search terms that are substantively unrelated to the constitutional analysis at issue. ${ }^{139}$

The final approach is limited to permutations of the term "history." The inclusion of "history" as a tradition-related search term creates a potential problem of over-inclusiveness in the dataset, as simple references to history implicate a much broader range of analytical approaches than the comparatively limited concept of traditionalism. ${ }^{140}$ It is thus important to protect against positive indicators for traditionalism where a reference to history is only included as part of an originalist analysis. The "Originalism" and "Originalism Frequency" variables address this issue by identifying occurrences of the term "history" that served as a positive indicator of traditionalism yet were used explicitly in an originalist analysis.

The second, and far less likely, way in which an over-inclusive result may occur in the instant dataset is where a case contains constitutional references and

\footnotetext{
${ }^{137}$ For concerns about the ability of Lawyer's Edition Headnotes to accurately describe a constitutional issue, see supra note 130 and accompanying text.

${ }^{138}$ See supra note 114 and accompanying text (describing the "Mode" variable).

${ }^{139}$ The most common (albeit infrequent) example of this is in unrelated discussions of, for instance, "the history of the litigation" in a part of the opinion otherwise identified as including a constitutional analysis. League of United Latin Am. Citizens v. Perry, 548 U.S. 399, 410 (2006).

${ }^{140}$ Whereas tradition connotes a dynamic process of developing and sustaining certain values and practices within a community, history is often used to refer to considerations of a specific person, place, or event in the past without any necessary consideration of the connection or relationship of those past events or circumstances with the present. See supra notes 42-46 and accompanying text (outlining the difference between traditionalism and originalism).
} 
U N I V E R S I T Y OF P I T T S B U R G H L A W R E V I E W

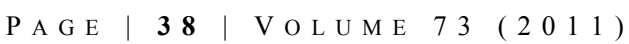

Headnotes but does not in actuality address any substantive constitutional issues. The inclusion of the "lawSupp" variable from the SCD is designed to protect against this by identifying the primary legal issues under consideration in the case. Where an opinion is coded as including a constitutional analysis but has a "lawSupp" entry that does not include any constitutional issues, this serves as a check against positively identifying as traditionalist cases that may merely refer to a constitutional provision without actually engaging in any analysis of that provision. $^{141}$

The possibility of under- and over-inclusive results is unavoidable in a coding exercise such as this one that seeks to identify in as objective a manner as possible the occurrence of a subjective phenomenon, such as a Justice's choice of constitutional interpretive methodology. Rather than run the risk of sacrificing the reliability of the vast majority of data by fashioning a more subjective coding protocol, additional variables were introduced to maximize transparency. This heightened transparency maintains a high measure of reliability in finding indicators of traditionalism, while providing enough additional information to create a full and accurate picture of the Court's use of tradition in its constitutional jurisprudence.

\section{Traditionalism and the Court}

The coding process offers some preliminary insights into the frequency and manner with which the various members of the Roberts Court have employed traditionalism in constitutional cases. It should be noted that the following observations are neither exhaustive of the range of hypotheses that may be tested using the coded data nor the product of any statistically supported evaluation. Moreover, due to the overwhelming lack of Headnotes in concurring and dissenting opinions, this analysis only includes data from majority and plurality opinions. ${ }^{142}$ Despite this modest scope, these findings are useful not only as a new source of information about the Roberts Court's actual practices in the area of constitutional interpretation, but as a testament to the dataset's vast potential for future inquiry.

\footnotetext{
${ }^{141}$ See, e.g., Will v. Hallock, 546 U.S. 345 (2006) (including a blank "lawSupp" entry in the SCD that functioned as a check against a case containing a Headnote that referenced the Double Jeopardy Clause of the Fifth Amendment despite engaging in statutory interpretation).

${ }^{142}$ See supra note 111 and accompanying text (explaining that $96.8 \%$ of concurring and/or dissenting opinions do not contain Lawyer's Edition Headnotes).
} 


\section{A. Frequency}

The Roberts Court has regularly relied on traditionalism in constitutional cases. Although this study did not consider whether traditionalism was the only or even the primary method of constitutional interpretation in any given opinion, traditionalism was evident to some degree in a minimum of $44 \%(49 / 111)^{143}$ of all constitutional cases decided by the Roberts Court in its first five years. ${ }^{144}$

143 The forty-nine cases cited as positive for traditionalism were culled from a total of sixty-two positively coded cases after accounting for potential over-inclusiveness in the data. These potentially false positive results were identified by reviewing the "Type," "Mode," and "Originalism" variables for every tradition-related term in every case that included a positive indicator for traditionalism. For instance, the case of Skilling v. United States, 130 S. Ct. 2896 (2010), included the term "history" in a portion of the opinion dealing with the interpretation of a constitutional provision, and as such was coded as positive for traditionalism. But the occurrence of the term "history" that triggered a positive result in the dataset was, in fact, part of the title of the "Museum of Natural History." Id. at 2914 n.12. The "Mode" variable for that case was thus a "9," indicating that although the term appeared in a portion of the opinion designated as involving a constitutional analysis, it did not, in fact, represent a traditionalist analysis because the occurrence of the term was entirely incidental to the substance of the Court's reasoning. League of Latin Am. Citizens v. Perry, 548 U.S. 399 (2006), is another example of a case that appeared to include a positive indicator for traditionalism but, in fact, was the result of overinclusiveness. Perry included one occurrence of the term "history" that served as a positive indicator of traditionalism. As reported in the "Type" variable for that case, however, that occurrence of the term "history" was part of a reference to the "history of the litigation," and as such was not an accurate indication of the use of traditionalism in the opinion. Id. at 410 . Finally, the "Originalism" variable acted as a safety net in the case of Polar Tankers, Inc. v. City of Valdez, Alaska, 129 S. Ct. 2277 (2009), in which the Tonnage Clause of Article I was interpreted using a permutation of "history," only to discover on further review of the data that the use of "history" in that context was an explicit reference to the history of the drafting of that provision, and as such is better characterized as an originalist, rather than a traditionalist, reference. $I d$. at 2283 (interpreting the Tonnage Clause based at least in part on "the history of the adoption of the Clause").

Of the thirteen total cases that contained positive indicators for traditionalism but were identified as potentially over-inclusive, eleven of those cases were so identified using variables in the dataset. In other words, the dataset proved sufficiently transparent to allow for identification of the vast majority of potentially over-inclusive results without resorting to any additional review. The remaining two cases were reviewed once more for over-inclusiveness by reading the portion of the opinion under the relevant Headnote(s) that led to the positive result and determining whether the tradition-related term in question was, in fact, not part of a constitutional analysis. Where the answer to this question was clearly no, that case was also excluded from the final count of positive indicators. See supra notes 133-41 and accompanying text (discussing the different approaches taken in designing this study to protect against over-inclusiveness). The final result is a conservative, independently verified report of those cases in which the Court employs tradition-related search terms as part of constitutional analyses. Although at first glance it may appear as if the subjective nature of this review may eclipse all of the other data collection procedures, it is important to note that the final review for over-inclusiveness was done only for those cases that were already coded as including positive indicators for traditionalism, and only as a search for clear indications that such over-inclusiveness existed in the dataset. The result was that only two cases were identified as over-inclusive using this approach, and in both of those cases the 


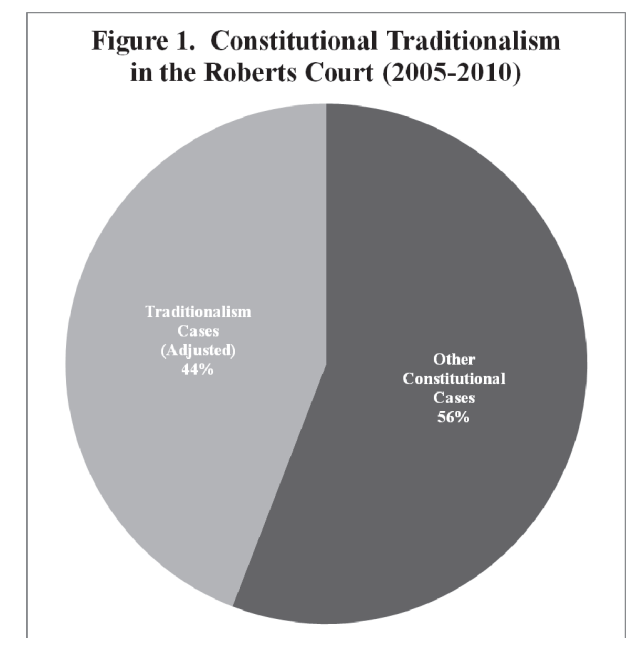

In addition to quantifying the total number of cases that include positive indicators for traditionalism, the dataset also includes information on the number of different tradition-related search terms employed in a traditionalist analysis, and on the number of times in a given opinion a specific tradition-related term was used in constitutional interpretation. Of the forty-nine cases presenting as positive for traditionalism, twenty-five involved more than one of the tradition-related search terms as a positive indicator of traditionalism. This includes more than half of the traditionalist cases identified by this study, as well as almost one-fourth $(25 / 111$, or $24 \%$ ) of all constitutional cases decided by the Roberts Court in its first five terms.

determination was debatable. See Hertz v. Friend, 130 S. Ct. 1181 (2010); Bartlett v. Strickland, 556 U.S. 1 (2009). In the interest of maintaining a conservative view toward reporting positive instances of traditionalist reasoning, however, these two cases were excluded from the final report of traditionalist cases.

${ }^{144}$ See infra Figure 1. The number of "constitutional cases" decided by the Roberts Court was calculated from information available in the SCD. The calculation relied on the version of the SCD dataset described as "Case-Centered Data" and "Cases Organized by Issue/Legal Provision." See THE SuPreme COURT DATABASE, supra note 95. This version of the dataset was chosen for present purposes because its "lawSupp" variable reports the legal provision(s) involved in every Supreme Court decision, including when the Court applied more than one legal authority in a given case, and because its "Case ID" variable identifies when multiple case names and docket numbers are in reality part of a single case before the Court. The result is a count of every instance in which a single Supreme Court case involved the interpretation of a constitutional provision. This data is even more appropriate for present purposes because the SCD's "lawSupp" variable generally does not include entries for the application of constitutional principles - such as federalism or separation of powers - that are not implicated in the Court's discussion of a specific textual provision of the Constitution. See discussion supra note 77 and accompanying text (explaining that this project does not seek to code for instances where traditionalism was used in conjunction with constitutional principles, but only textual provisions of the Constitution). 
It is important because it represents a significant subset of even stronger positive indicators for traditionalism than those positively identified cases that only include one of the tradition-related terms in a constitutional analysis.

Moreover, of the forty-nine cases containing positive traditionalism indicators, thirty-one have multiple positive occurrences of one or more traditionrelated terms. This demonstrates that about two-thirds (approximately 65\%) of the positively coded constitutional cases employ at least one tradition-related search term multiple times as part of a constitutional analysis. Put another way, only about one-third of the cases offering positive indicators of traditionalism do so through single occurrences of a tradition-related search term or terms. Combining these last two pieces of information reveals that thirty-five of the forty-nine positively coded cases contained either multiple terms within the same opinion, multiple occurrences of a single term, or both. This amounts to strong traditionalism indicators in about $73 \%$ of all positive cases and about $31 \%$ of the entire Roberts Court's portfolio of constitutional decisions in its first five terms.

While certainly not an exhaustive examination of the prominence of traditionalist analysis in the Roberts Court's constitutional jurisprudence, the evidence presented nonetheless provides the first empirical support for the general conclusion that traditionalism is a significant contributor to the Court's constitutional jurisprudence. ${ }^{145}$ This is both a valuable piece of information to the ongoing debate about constitutional theory in the current Court, ${ }^{146}$ as well as a (previously unavailable) confirmation of the significance of traditionalism in modern constitutional law that serves as support for additional empirical and theoretical inquiry.

\footnotetext{
${ }^{145}$ This discussion of the frequency with which traditionalism occurs does not, for example, include any mention of the litany of additional data points that are included in the dataset for this project and that provide interesting material for future research. Information pertaining to the subject matter of each case, the prevailing party, and the degree of public interest in the matter, as well as information pertaining to the ideological makeup of the authoring Justice and the names of the Justices that signed onto the opinion are all interesting pieces of information from which to develop important additional questions and research. See infra Part V (highlighting future scholarly applications of the instant dataset).

${ }^{146}$ See generally Michael P. Allen, The Roberts Court and How to Say What the Law Is, 40 STETSON L. REV. 701 (2011) (discussing the Roberts Court's conscious articulation of interpretive rules in its constitutional jurisprudence).
} 


\title{
B. Breadth (Traditionalism by Constitutional Provision)
}

Beyond its general prevalence in constitutional cases, it is also important to consider traditionalism's relevance across constitutional provisions. ${ }^{147}$ From the beginning of the Roberts Court's tenure in October 2005 until the start of its 2010 term, the Court decided 111 cases in which it addressed a constitutional issue. ${ }^{148}$ Those 111 cases considered, according to the SCD, thirty different constitutional provisions. ${ }^{149}$ Of those thirty constitutional provisions, twenty were viewed in at least one instance through a traditionalist lens. Of the ten provisions that did not include any traditionalist analysis, six were discussed in only one case during the relevant time period. Put another way, only four of the thirty constitutional provisions addressed by the Roberts Court in its first five years were considered more than once without also incorporating some positive indicator of traditionalism.

A similar correlation exists when we focus on provisions that appear more than once in the Roberts Court's constitutional jurisprudence. Eighteen constitutional provisions were treated more than once by the Roberts Court in its

${ }^{147}$ Cass Sunstein argues that context is a potentially important feature in establishing the merits of traditionalist interpretation:

\begin{abstract}
Under some constitutional provisions, above all the Equal Protection Clause, the Burkean approach is hard or perhaps impossible to square with entrenched understandings in American constitutional law-and hence turns out to be self-contradictory. The reason is that some areas of doctrine have long operated on non-Burkean or even anti-Burkean premises .... But in other domains, the Burkean approach can claim both to be consistent with existing law and to operate in a way that imposes appropriate discipline on judicial judgments. In the areas of separation of powers and national security, for example, Burkean minimalism deserves to have, and indeed has had, a major role, as the Court has proceeded via small steps and with close attention to institutional practices extending over time.
\end{abstract}

Sunstein, Minimalism, supra note 4, at 400-01. In light of this point of view, evidence of the contexts in which traditionalism is actually employed by the Supreme Court becomes even more instructive.

${ }^{148}$ See supra note 144 (explaining how the number of constitutional cases by the Roberts Court was calculated).

${ }^{149}$ In general, the SCD defines constitutional provisions at the level of individual clauses, not simply by an Article or Amendment. See SPAETH ET AL., supra note 99, at A22. In light of the possibility that a single case will involve the interpretation of multiple constitutional provisions, the data pertaining to the number of constitutional cases and provisions taken up by the Roberts Court was gathered from the version of the SCD that allowed for multiple "lawSupp" entries for each case. See THE SUPREME COURT DatABASE, supra note 95 ("Cases Organized by Issue/Legal Provision" dataset). This permitted identification of both constitutional cases and of constitutional provisions in cases where nonconstitutional issues were also relevant. 
first five years. Fourteen of those eighteen provisions (about 78\%) include a positive indicator for traditionalism, and eleven of those eighteen provisions (more than $61 \%$ ) include more than one positive indication. Without intending to prove too much, these data points provide evidence of the trans-substantive nature of traditionalism's impact on constitutional law; traditionalism affects the Court's understanding and interpretation of the Constitution's limitations of government power and structure and of its protection of individual rights. ${ }^{150}$

More specifically, a provision-by-provision analysis provides insight into any specific doctrinal trends favoring traditionalism. Some of the more obvious correlations are with the Commerce Clause, ${ }^{151}$ the Case and Controversy requirement of Article III, ${ }^{152}$ and the Fourth, ${ }^{153}$ Sixth ${ }^{154}$ and Fourteenth Amendments. ${ }^{155}$

\section{The Dormant Commerce Clause}

The Roberts Court took up three cases dealing with the Commerce Clause in its first five terms. All three addressed the Dormant Commerce Clause, ${ }^{156}$ and all three also incorporated some measure of traditionalism. Tradition in these cases embodies principles of federalism; it is used to help designate enclaves of existing state authority in areas otherwise treated as federal. In United Haulers Ass'n $v$. Oneida-Herkimer Solid Waste Management Authority, ${ }^{157}$ the Court upheld a flow control ordinance requiring all solid waste generated within two counties to be delivered to the processing facilities of a local public benefit corporation. In explaining its decision, the Court explained that "[w]e should be particularly hesitant to interfere with the Counties' efforts under the guise of the Commerce Clause because '[w]aste disposal is both typically and traditionally a local

\footnotetext{
${ }^{150}$ See infra Figure 2.

${ }^{151}$ U.S. CONST. art. I, $\S 8$, cl. 3 ("The Congress shall have Power . . [t] regulate commerce with foreign nations, and among the several States ....”).

${ }^{152}$ U.S. CONST. art. III, § 2, cl. 1 (“The judicial Power shall extend to all Cases . . [and] Controversies ....").

${ }^{153}$ U.S. CONST. amend. IV.

${ }^{154}$ U.S. CONST. amend. VI.

${ }^{155}$ U.S. CONST. amend. XIV.

${ }^{156}$ See Dep't of Revenue v. Davis, 553 U.S. 328 (2008); MeadWestvaco Corp. v. Illinois Dep't of Revenue, 553 U.S. 16 (2008); United Haulers Ass'n v. Oneida-Herkimer Solid Waste Mgmt. Auth., 550 U.S. 330 (2007).

${ }^{157}$ United Haulers Ass' $n, 550$ U.S. at 344.
} 
government function." "158 Similarly, the Court in Department of Revenue $v$. Davis $^{159}$ upheld a state income tax on interest from out-of-state municipal bonds because the "century-old taxing practice" employed by the state was a "traditional government function." 160 In MeadWestvaco Corp. v. Illinois Department of Revenue, the Court applied the unitary business principle to determine whether a state tax on capital gains from the sale of a division of an out-of-state corporation violated the Dormant Commerce Clause. ${ }^{161}$ In addressing the lower courts' application of the unitary business principle, the Court explained that the "history of this venerable principle ... figures prominently in this case,"162 and traced the development of the principle as it "evolved in step with American enterprise" 163 from the Industrial Revolution through the Court's modern jurisprudence.

\section{Article III Standing}

The question of standing under the Case or Controversy requirement of Article III has been another forum for traditionalism under the Roberts Court. Standing issues arose in nine cases during the Roberts Court's first five years, and three of those nine cases referred to tradition. Traditionalism serves in this context as a vehicle for articulating concerns about the separation of powers that are inextricably intertwined with the concept of judicial review. ${ }^{164}$ It manifests in

\footnotetext{
${ }^{158} I d$. at 344 (emphasis added).
}

${ }^{159} 533$ U.S. 328.

${ }^{160} I d$. at 342. The Court's use of the "traditional state function" test in United Haulers and Davis is particularly interesting for two reasons. First, the standard was generally reputed by the Court in the Tenth Amendment context. See Garcia v. San Antonio Metro. Transit Auth., 469 U.S. 528 (1985). Second, the test has generally not been a focal point of the Court's previous Dormant Commerce Clause jurisprudence. See United Haulers Ass'n, 550 U.S. at 369 (Alito, J., dissenting) (arguing, without any contradictory citations by the majority, that the use of the traditional state function test is unsupported by precedent). See generally John J. Greffet, Jr., Factoring in Tradition: The Proper Role of the Traditional Governmental Function Test, 53 ST. LouIs U. L.J. 875 (2009) (discussing the traditional state function test in, inter alia, the Court's Dormant Commerce Clause jurisprudence).

${ }^{161}$ MeadWestvaco, 533 U.S. at 24 (mentioning the parallel nature of the analysis under the Due Process Clause of the Fourteenth Amendment, but focusing on the unitary business principle, which sounds more directly under the Dormant Commerce Clause).

${ }^{162} I d$. at 26.

${ }^{163} I d$. at 27.

${ }^{164}$ The constitutional difficulties surrounding judicial review have been the topic of much judicial and scholarly treatment, and were perhaps most famously described by Alexander Bickel as the "countermajoritarian difficulty" of Supreme Court review of democratic, political institutions. See, e.g., BICKEL, supra note 4 , at 16 ("The root difficulty is that judicial review is a counter-majoritarian force in our system."). 
discussions about the traditional role of the courts in constitutional government. ${ }^{165}$ Most notable among these is the Sprint case, ${ }^{166}$ in which Justice Breyer explained that "history and tradition offer a meaningful guide to the types of cases that Article III empowers federal courts to consider," ${ }^{167}$ and then addressed the specific issue in that case - the ability of assignees to bring suit—by explaining that "there is a strong tradition specifically of suits by assignees for collection. We find this history and precedent 'well nigh conclusive' in respect to the issue before us: Lawsuits by assignees, including assignees for collection only, are 'cases and controversies of the sort traditionally amenable to, and resolved by, the judicial process." ${ }^{\prime 168}$ Justice Breyer's heavy reliance on traditionalism says much about the importance of the concept of tradition to Article III standing.

The Court in Summers v. Earth Island Institute ${ }^{169}$ and Massachusetts v. $E P A^{170}$ echoed the significance of tradition to the law of constitutional standing. The Summers Court explained that "[i]n limiting the judicial power to 'Cases' and 'Controversies,' Article III of the Constitution restricts it to the traditional role of Anglo-American courts." ${ }^{, 171}$ The Court in Massachusetts described the words "Cases" and "Controversies" as "confin[ing] "the business of federal courts to questions presented in an adversary context and in a form historically viewed as capable of resolution through the judicial process." ${ }^{1172}$ While each of these cases only invoked the concept of tradition once, both did so in describing the most basic tenets of Article III "Cases" and "Controversies," such that even these brief

\footnotetext{
${ }^{165}$ See Summers v. Earth Island Inst., 555 U.S. 488 (2009); Sprint Commc'ns Co. v. APCC Services, Inc., 554 U.S. 269 (2008); Massachusetts v. EPA, 549 U.S. 497 (2007). Two other standing cases during the Roberts Court's tenure were excluded from the list of positive indicators of traditionalism on the basis that they were potentially over-inclusive, despite the fact that an argument could be made for each as including a traditionalist analysis. See Daimler Chrysler v. Cuno, 547 U.S. 332 (2006) (using the term "history" in an originalist, rather than a traditionalist, sense); Hertz Corp. v. Friend, 130 S. Ct. 1181 (2010).

${ }^{166}$ Sprint, 554 U.S. 269.

${ }^{167} I d$. at 274 .

${ }^{168}$ Id. (quoting Vermont Agency of Natural Res. v. United States ex rel. Stevens, 529 U.S. 765, 777-78 (2000)).

${ }^{169} 555$ U.S. 488.

${ }^{170}$ Massachusetts, 549 U.S. 497.

${ }^{171}$ Summers, 555 U.S. 492.

${ }^{172}$ Massachusetts, 549 U.S. at 516 (quoting Flast v. Cohen, 392 U.S. 83, 95 (1968)).
} 
invocations of traditionalism must be taken seriously in understanding constitutional judicial power.

\section{The Fourth Amendment}

Traditionalism's impact on specific constitutional provisions is not limited, however, to the original document. In fact, some of the strongest correlations with tradition are evident in the Amendments, more precisely among certain provisions of the Bill of Rights and the Fourteenth Amendment. The Fourth Amendment was featured in fifteen decisions of the Roberts Court during its first five terms, ${ }^{173}$ five of which included positive indicators of traditionalism. In the Fourth Amendment context, traditionalism plays a definitional role; ${ }^{174}$ it provides a means of gauging reasonableness that at least claims to be both less susceptible to individual judicial attitudes and more faithful to the text and to history. In Virginia v. Moore ${ }^{175}$ this is apparent in the Court's reliance on "traditional standards" for determining reasonableness ${ }^{176}$ and in its search for answers that "existed in 1791 and ha[ve] been generally adhered to by the traditions of our society ever since" in evaluating whether the Fourth Amendment incorporates statutory standards. ${ }^{177}$ The Court further explored the definition of Fourth Amendment reasonableness through traditionalism in Georgia v. Randolph, ${ }^{178}$ where it addressed the question of whether an occupant may give law enforcement consent to search against the wishes of a co-tenant. In considering the question of who possesses ultimate authority to permit a search, the Court engaged in a detailed discussion of our social customs and understandings of such authority, culminating in its explanation

\footnotetext{
${ }^{173}$ The fifteen cases cited as interpreting the Fourth Amendment include one coded by the SCD as invoking the evidentiary exclusionary rule based on Fourth Amendment protections. See Herring v. United States, 555 U.S. 135 (2009).

${ }^{174}$ Traditionalism functions similarly in the Roberts Court's Eighth Amendment jurisprudence, albeit in a less consistent fashion. In interpreting the meaning of the Amendment's prohibition on "cruel and unusual" punishment, the Court has invoked the "history of the death penalty" for the crime at issue, Kennedy v. Louisiana, 554 U.S. 407, 422 (2008), and cited authorities that support "looking to "historical development of the punishment at issue"' in determining whether the Eighth Amendment prohibits a specific punishment. Id. at 421 (quoting Enmund v. Florida, 458 U.S. 782, 788 (1982)). It also looked to whether potentially mitigating evidence in a capital case was "traditional sentence-related evidence" to determine whether its exclusion from the sentencing phase violated the Eighth and Fourteenth Amendments. Oregon v. Guzek, 546 U.S. 517, 524 (2006).

175553 U.S. 164 (2008).

${ }^{176} I d$. at 171.

${ }^{177} \mathrm{Id}$.

${ }^{178} 547$ U.S. 103 (2006).
} 
that "the 'right' to admit the police ... is . . . the authority recognized by customary social usage as having a substantial bearing on Fourth Amendment reasonableness." ${ }^{, 179}$ In Hudson v. Michigan, ${ }^{180}$ the Court again invoked traditionalism when it cited the "traditional protection" of the knock-and-announce rule as "a command of the Fourth Amendment," at least in part due to the rule's "origins in our English legal heritage.",181

\section{The Sixth Amendment}

The Sixth Amendment also displays a notable connection with traditionalism under the Roberts Court. Of twenty-one Roberts Court cases interpreting the Sixth Amendment, ten incorporate traditionalism. ${ }^{182}$ The SCD isolates six sub-issues within the Sixth Amendment, ${ }^{183}$ all of which have been addressed at least once by the Roberts Court. Three of those sub-issues - the right of confrontation, the right to counsel, and the right to trial by jury — have been addressed using a traditionalist analysis, and two of the three remaining sub-issues were considered in only one case each. ${ }^{184}$ Of the three sub-issues under the Sixth Amendment that have incorporated a traditionalist analysis, two of them - the rights to confrontation and trial by jury - have included a traditionalist analysis in six of the seven cases decided by the Roberts Court. Four of five confrontation cases and both cases considering the right to trial by jury included references to tradition as part of their constitutional analyses. ${ }^{185}$ In these cases, traditionalism is used primarily to incorporate features of the common law adversarial litigation system into the Sixth Amendment's protections. For example, in Melendez-Diaz v. Massachusetts, ${ }^{186}$

${ }^{179}$ Id. at $120-21$.

${ }^{180} 547$ U.S. 586 (2006).

${ }^{181} \mathrm{Id}$. at 589.

${ }^{182}$ See supra Figure 1.

${ }^{183}$ Within the Sixth Amendment, the SCD codes for the following sub-issues: "Right to Confront," "Right to Counsel," "Right to Trial by Jury," "Speedy Trial," "Other Provisions," and the "Exclusionary Rule" based on the right to counsel. See SPAETH ET AL., supra note 99, at A22 (codes 213-17 and 503).

${ }^{184}$ Those sub-issues that were only considered once by the Roberts Court are the right to a speedy trial and the evidentiary exclusionary rule based on the right to counsel. The final sub-issue under the Sixth Amendment is described by the Supreme Court Database Code Book as "other provisions," and has included four cases since the beginning of the Roberts Court's tenure, none of which included positive indicators for traditionalism.

${ }^{185}$ In fact, there is a third Roberts Court decision that employs traditionalism in interpreting the Sixth Amendment right to trial by jury, see Dillon v. United States, 130 S. Ct. 2683 (2010), but this is not included in the calculation because it was not designated as a constitutional case by the SCD.

${ }^{186} 129$ S. Ct. 2527 (2009). 
Justice Scalia's majority opinion invoked the "deeply rooted common-law tradition "of live testimony in court subject to adversarial testing"' in delineating the boundaries of the Confrontation Clause, ${ }^{187}$ and in Giles v. California, ${ }^{188}$ the Court considered whether the State's proposed exception to the right of confrontation "had a historical pedigree in the common law" or in any aspect of American jurisprudence "since the founding." 189 Similarly, in Oregon v. Ice, ${ }^{190}$ Justice Ginsburg, writing for a majority, considered "the jury's traditional domain"191 in evaluating whether the imposition of consecutive sentences based on facts found by the court violated a defendant's Sixth Amendment right to a jury trial. This decision came after the Court's opinion in Cunningham v. California, ${ }^{192}$ where the Court, after addressing the validity of the California Supreme Court's reliance on the traditional fact-finding function of the jury to establish whether a sentence ran afoul of the Sixth Amendment, ${ }^{193}$ acknowledged that its controlling interpretation of the Sixth Amendment right to a jury trial "is rooted in longstanding commonlaw practice" and is the product of an examination of "the Sixth Amendment's historical and doctrinal foundations." 194

\section{The Fourteenth Amendment}

With regard to the Roberts Court's Fourteenth Amendment cases, almost twothirds (ten of sixteen) invoked traditionalism. When the Fourteenth Amendment cases are divided along Equal Protection and Due Process Clause lines, ${ }^{195}$ we find that although the Roberts Court considered a similar number of cases under the Due Process Clause (nine) as under the Equal Protection Clause (seven), traditionalism did not have a similar effect in each category; traditionalism played a role in eight of the nine Due Process Clause cases but only in two of the seven

${ }^{187} \mathrm{Id}$. at 2534 .

${ }^{188} 554$ U.S. 353 (2008).

${ }^{189} \mathrm{Id}$. at 366.

${ }^{190} 555$ U.S. 160 (2009).

${ }^{191} I d$. at 168 .

192549 U.S. 270 (2007).

${ }^{193}$ Id. at 289 (referring to the "type of factfinding that traditionally has been incident to the judge's selection of an appropriate sentence").

${ }^{194} I d$. at 281 .

${ }^{195}$ According to the SCD, none of the other provisions in the Fourteenth Amendment were addressed by the Roberts Court in its first five terms. See The Supreme Court Database, supra note 95 ("Cases Organized by Issue/Legal Provision" dataset). 
cases under the Equal Protection Clause. This difference across the two clauses is not surprising in light of the powerful presence of traditionalism in the Court's substantive due process jurisprudence, ${ }^{196}$ especially when contrasted with the common understanding of the Equal Protection Clause as designed to overcome, rather than promote, traditional or historical practices. ${ }^{197}$ A closer look, however, gives cause to rethink the assumption that tradition has little to say about equal treatment under the law.

Three of the Roberts Court's Due Process Clause cases incorporated traditionalism explicitly through use of the well-known substantive due process inquiry into whether a right implicates a "principle of justice so rooted in the traditions and conscience of our people as to be ranked as fundamental." 198 While this use of traditionalism is the most commonly discussed in accordance with the Due Process Clause, ${ }^{199}$ it is not the only role for traditionalism in the Roberts Court's due process jurisprudence. For example, in Holmes v. South Carolina, ${ }^{200}$ the Court applied traditionalism in a procedural context, referring to "traditional and fundamental standards of due process" to delineate the constitutional protection afforded a criminal defendant seeking to introduce evidence excluded at trial, and went on to explain that due process required the type of determinations "that have traditionally been reserved for the trier of fact. ${ }^{201}$ In Indiana v. Edwards, ${ }^{202}$ the

${ }^{196}$ See, e.g., Moore v. City of E. Cleveland, Ohio, 431 U.S. 494, 503 (1977) (protecting a substantive individual right under the Due Process Clause of the Fourteenth Amendment because it "is deeply rooted in this Nation's history and tradition").

${ }^{197}$ See, e.g., Sunstein, Against Tradition, in THE COMmUnitarian Challenge to LiBeralism, supra note 61, at 218 ("Tradition deserves a place under the due process clause [sic] as a way of preventing abuses under that otherwise open-ended clause .... But tradition is not a good guide to the meaning of the equal protection clause [sic], which was specifically designed as a check on traditions . ...").

198 McDonald v. City of Chicago, 130 S. Ct. 3020, 3036 (2010) (explaining that the "Second Amendment right to keep and bear arms is incorporated in the concept of due process" because "this right is 'deeply rooted in this Nation's history and tradition." (quoting Washington v. Glucksberg, 521 U.S. 702, 721 (1997)); DA's Office v. Osborne, 129 S. Ct. 2308, 2320 (2009) (acknowledging the test for a due process violation as whether the State's conduct "offends some principle of justice so rooted in the traditions and conscience of our people as to be ranked as fundamental"); Clark v. Arizona, 548 U.S. 735,779 (2006) (holding that there was no violation of the defendant's due process rights because there is "no cause to claim that channeling evidence on mental disease and capacity offends any "principle of justice so rooted in the traditions and conscience of our people as to be ranked as fundamental."').

${ }^{199}$ See, e.g., Sunstein, supra note 50.

${ }^{200} 547$ U.S. 319 (2006).

${ }^{201} I d$. at 325-26, 330.

${ }^{202} 554$ U.S 164 (2008). 
Court again discussed the Due Process Clause's impact on procedural questions when it relied on the "absence of historical examples of forced representation" as one of four factors supporting the existence of a criminal defendant's constitutional right to proceed without counsel under the Sixth and Fourteenth Amendments. ${ }^{203}$ Similarly, in Caperton v. A.T. Massey Coal Company, ${ }^{204}$ the Court noted that "the traditional common-law prohibition on direct pecuniary interest" is relevant to an analysis of judicial bias under the Due Process Clause. ${ }^{205}$ Finally, in Philip Morris USA v. Williams ${ }^{206}$ the Court invoked traditionalism in yet another way under the Due Process Clause when it referred to "the longstanding historical practice of setting punitive damages" in determining whether a damage award violated due process. $^{207}$ These examples serve not only to confirm the well-documented role of traditionalist analysis with regard to substantive due process, but to demonstrate that tradition serves other functions as well in the Roberts Court's treatment of the Fourteenth Amendment's Due Process Clause.

The Roberts Court's Equal Protection Clause jurisprudence implicates tradition less frequently than its Due Process Clause cases do. But in those few instances when it did rely on traditionalism as part of an equal protection analysis, it did so rather directly. In Engquist v. Oregon Department of Agriculture, ${ }^{208}$ the Court referred to the "historical understanding of the nature of government employment" in rejecting a claim that the Equal Protection Clause protects public employees from arbitrary personnel decisions by their government employers. ${ }^{209}$ In the case of Parents Involved in Community Schools v. Seattle School District No. $1,{ }^{210}$ in which equal protection challenges were brought against two separate school

${ }^{203} I d$. at 171.

204129 S. Ct. 2252 (2009).

${ }^{205}$ Id. at 2260. The Court in Jones v. Flowers, 547 U.S. 220 (2006), offered yet another example of procedural questions inspiring traditionalist responses when it noted that our cultural understanding of proper notice is relevant in a procedural due process analysis. Analogizing the case at hand to Miranda v. Arizona, 384 U.S. 436 (1966), the Flowers Court acknowledged that although the right to remain silent is "part of our national culture," that does not alleviate the due process requirement that explicit instructions regarding the right be given to arrestees. 547 U.S. at 233 (quoting Dickerson v. United States, 530 U.S. 428,443 (2000)).

${ }^{206} 549$ U.S. 346 (2007).

${ }^{207} I d$. at 351 .

${ }^{208} 553$ U.S. 591 (2008).

${ }^{209}$ Id. at 594.

${ }^{210} 551$ U.S. 701 (2007). 
districts for using race in assigning children to public schools, traditionalism appeared frequently and in varied ways; Chief Justice Roberts' plurality opinion drew on the historical features of racism ${ }^{211}$ (especially school segregation), ${ }^{212}$ the role of higher (as opposed to primary and secondary) education in our "constitutional tradition,", ${ }^{213}$ and the diversity in cultures and traditions that helps define American values. ${ }^{214}$ Notwithstanding the fact that these are only two examples of cases in which the Roberts Court undertook an equal protection analysis with reference to the concept of tradition, both of these examples demonstrate a strong place in the Court's reasoning for traditionalist ideas, a reality that is interesting in part because it is somewhat inconsistent with the broader normative understandings of the Equal Protection Clause's purpose and function. ${ }^{215}$

\section{Other Provisions}

Finally, there are other constitutional provisions and issues which show a connection with traditionalism under the Roberts Court but in smaller proportions or sample sizes. ${ }^{216}$ The best example of traditionalism playing a notable role in a small portion of the cases interpreting a provision is in the Free Speech Clause of the First Amendment. Less than one-fourth (four of eighteen) of the Roberts Court

\footnotetext{
${ }^{211} I d$.

${ }^{212}$ See, e.g., id. at 735 (arguing that to permit racially influenced student assignments would invoke "our Nation's history of using race in public schools"); id. at 742 (contending that the use of benign racial classifications is unwise, as "[h]istory should teach greater humility. . . '[B]enign' carries with it no independent meaning, but reflects only acceptance of the current generation's conclusion that a politically acceptable burden, imposed on particular citizens on the basis of race, is reasonable." (quoting Metro Broad., Inc. v. FCC, 497 U.S. 547, 609-10 (1990) (O'Connor, J., dissenting))); id. at 746 ("Government action dividing us by race is inherently suspect because such classifications promote 'notions of racial inferiority and lead to a politics of racial hostility' [and] 'reinforce the belief, held by too many for too much of our history, that individuals should be judged by the color of their skin ....'” (citations omitted))

${ }^{213}$ Parents Involved in Cmty. Sch., 551 U.S. at 724.

${ }^{214} I d$. at 723 (noting as important that, in the plans at issue, race is not considered as part of a broader effort to achieve what previous Courts have recognized as a constitutionally valid goal in public education: "exposure to widely diverse people, cultures, ideas, and viewpoints"); id. at 723-24 ("We are a Nation not of black and white alone, but one teeming with divergent communities knitted together by various traditions and carried forth, above all, by individuals.") (quoting Metro Broad., Inc. v. FCC, 497 U.S. 547, 610 (1990) (O’Connor, J., dissenting))).

${ }^{215}$ See, e.g., Sunstein, Against Tradition, in The Communitarian Challenge to Liberalism, supra note 61, at 218 ("Tradition deserves a place under the due process clause [sic] as a way of preventing abuses under that otherwise open-ended clause .... But tradition is not a good guide to the meaning of the equal protection clause [sic], which was specifically designed as a check on traditions ....").

${ }^{216}$ See infra Figure 2.
} 
cases interpreting the Free Speech Clause incorporated traditionalism. ${ }^{217}$ Where traditionalism was implicated by the Court in connection with the Free Speech Clause, however, it was generally done to significant effect. In Pleasant Grove City v. Summum, ${ }^{218}$ Justice Alito's opinion for the Court depended in large part on whether a public park was a "traditional public forum." ${ }^{219}$ The Court in Christian Legal Society Chapter of the University of California, Hastings College of Law v. Martinez $^{220}$ considered whether a traditional public forum existed for student groups at a public university ${ }^{221}$ and evaluated the University's reasonableness in requiring that a student group retain an open membership policy based in part on the lack of any historical support for the contention that open enrollment will lead to the "hijacking" of student groups by "saboteurs."222 In United States v. Stevens, ${ }^{223}$ the Court looked to whether there was any "tradition [of] excluding depictions of animal cruelty from 'the freedom of speech' codified in the First Amendment" ${ }^{, 24}$ before ruling that a statute forbidding the sale of depictions of animal cruelty ran afoul of constitutional speech protections. The much-debated decision in Citizens United v. Federal Election Commission ${ }^{225}$ struck down a ban on corporate independent expenditures for electioneering communications at least in part because "it is our law and our tradition that more speech, not less, is the governing rule" 226 and because "[g]overnments are often hostile to speech, but under our law and our tradition it seems stranger than fiction for our Government to

\footnotetext{
${ }^{217}$ See infra Figure 2.

${ }^{218} 555$ U.S. 460 (2009).

${ }^{219}$ Id. at 479 ("Public parks have been used, 'time out of mind, . . . for purposes of assembly, communicating thoughts between citizens, and discussing public questions,' . . but 'one would be hard pressed to find a "long tradition" of allowing people to permanently occupy public space with any manner of monuments."') (citations omitted).

${ }^{220} 130$ S. Ct. 2971 (2010).

${ }^{221}$ Id. at 2984 n.11, 2986 n.14 (noting the role of the "traditional public forum" in analyses under the Free Speech Clause).

${ }^{222} I d$. at 2992. While the Court's contention about the historical evidence of hijacking has been controversial, its inclusion here is entirely consistent with the study's commitment to cataloging all instances of traditionalism independent of their relative persuasiveness or weight in the overall analysis. See supra note 76 and accompanying text (explaining that every instance of traditionalism is included in the database).

${ }^{223} 130$ S. Ct. 1577 (2010).

${ }^{224} \mathrm{Id}$. at 1585 .

${ }^{225} 130$ S. Ct. 876 (2010).

${ }^{226} I d$. at 911.
} 
make this political speech [in the public dialogue preceding a federal election] a crime. ${ }^{227}$ Although there were numerous examples of free speech cases that did not appear to involve traditionalism, these examples reveal that even in contexts where traditionalism may not be a prominent interpretive tool, it still can be-and is-influential in specific instances.

There are also a number of examples of constitutional provisions that were only considered a small number of times by the Roberts Court, but that showed a connection with traditionalism in a high percentage of those cases. ${ }^{228}$ For instance, both of the Roberts Court's landmark Second Amendment decisions, District of Columbia v. Heller ${ }^{229}$ and McDonald v. City of Chicago, ${ }^{230}$ incorporated traditionalist reasoning, ${ }^{231}$ as did the Court's lone decisions under the Bankruptcy Clause, $^{232}$ the Necessary and Proper Clause, ${ }^{233}$ the Vesting Clause of Article II, ${ }^{234}$

${ }^{227}$ Id. at 917.

${ }^{228}$ The single case interpreting the Tonnage Clause, Polar Tankers, Inc. v. City of Valdez, 129 S. Ct. 2277 (2009), is omitted from this discussion because although it contained an historical analysis of the Clause, that analysis was focused solely on the history of the Clause's drafting, and, as such, was excluded from the list of positive cases in the dataset on the basis that it in fact represented an originalist, rather than a traditionalist, analysis.

${ }^{229} 554$ U.S. 570 (2008).

${ }^{230} 130$ S. Ct. 3020 (2010). McDonald also includes traditionalist indicators in connection with its incorporation analysis under the Fourteenth Amendment's Due Process Clause. Although the incorporation and Second Amendment analyses overlap, the instant data collection project accounted for differences in the constitutional provisions at issue in varying portions of the Court's analysis, and strong positive indicators of traditionalism were identified for the Court's reading of the Second Amendment as well as the Due Process Clause of the Fourteenth Amendment.

${ }^{231}$ Although both McDonald and Heller contained significant originalist components, there are also references in each to a broader, more traditionalist analysis. See, e.g., McDonald, $130 \mathrm{~S}$. Ct. at 3036 ("Heller makes it clear that this right is 'deeply rooted in this Nation's history and tradition."” (quoting Washington v. Glucksberg, 521 U.S. 702, 721 (1997))); Heller, 128 S. Ct. at 2817 ("We also recognize another important limitation on the right to keep and carry arms. Miller said, as we have explained, that the sorts of weapons protected were those 'in common use at the time.' We think that limitation is fairly supported by the historical tradition of prohibiting the carrying of 'dangerous and unusual weapons."') (citations omitted).

${ }^{232}$ See Cent. Va. Cmty. Coll. v. Katz, 546 U.S. 356 (2006). Although Katz is largely an originalist analysis, the Court does include broader historical sources and arguments to support its holding. $I d$. at 364 (citing the broader "history of discharges in bankruptcy proceedings" and the historical meaning of the term "discharge"); id. at 370 (contending that the Bankruptcy Power in Article I includes the power to abrogate state sovereign immunity because "courts adjudicating disputes concerning bankrupts' estates historically have had the power to issue ancillary orders ....").

${ }^{233}$ See United States v. Comstock, 130 S. Ct. 1949, 1958 (2010) ("We recognize that even a longstanding history of related federal action does not demonstrate a statute's constitutionality. A history of involvement, however, can nonetheless be 'helpful in reviewing the substance of a 


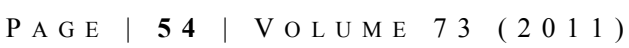

the Takings Clause, ${ }^{235}$ and the Eleventh Amendment. ${ }^{236}$

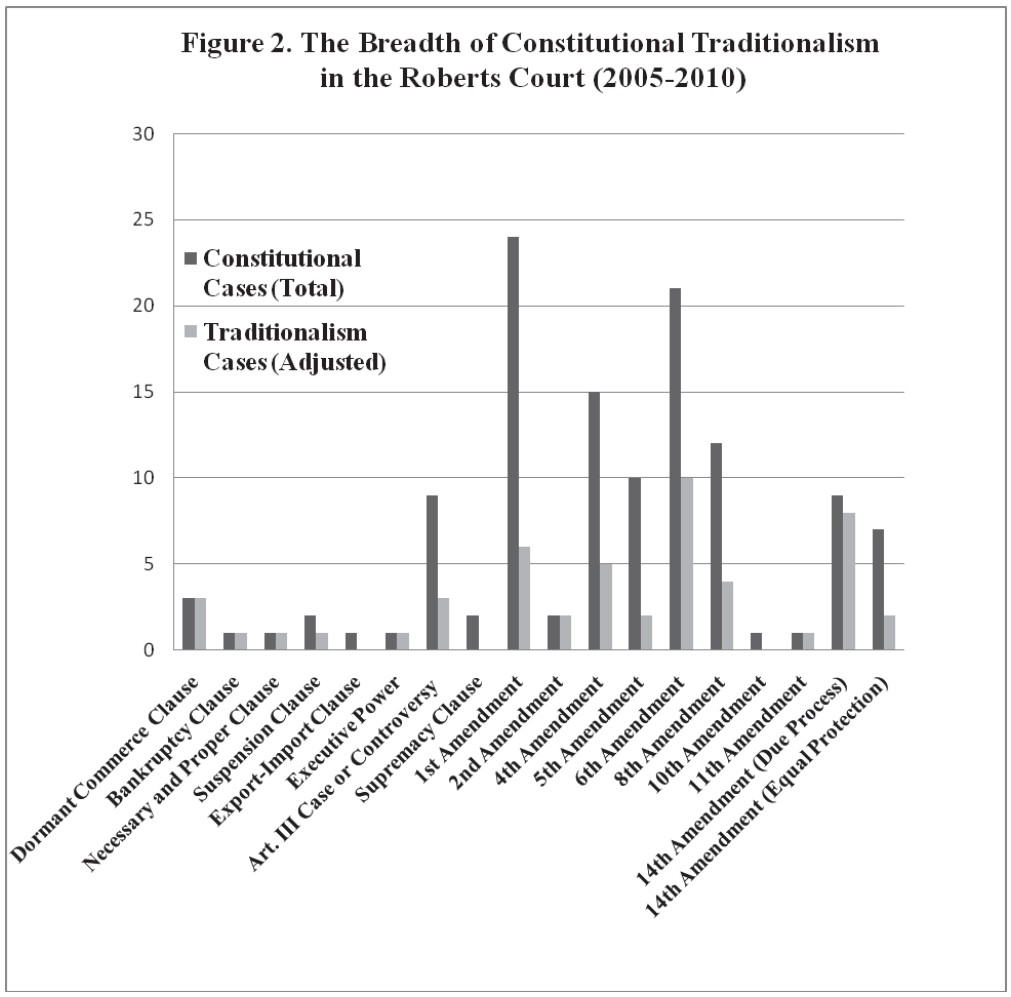

congressional statutory scheme' and, in particular, the reasonableness of the relation between the new statute and pre-existing federal interests." (quoting Gonzales v. Raich, 545 U.S. 1, 21 (2005))).

${ }^{234}$ See Free Enter. Fund v. Pub. Co. Accounting Oversight Bd., 130 S. Ct. 3138, 3161 (2010) (“Under the traditional default rule, removal is incident to the power of appointment."); id. at 3152 ("[T]he executive power included a power to oversee executive officers through removal; because that traditional executive power was not 'expressly taken away, it remained with the President."' (citation omitted)); Medellin v. Texas 552 U.S. 491, 531 (2008) ("[I]f pervasive enough, a history of congressional acquiescence can be treated as a 'gloss on "Executive Power" vested in the President by $\S 1$ of Art. II.”” (quoting Dames \& Moore v. Regan, 453 U.S. 654, 686 (1981))).

${ }^{235}$ See Stop the Beach Renourishment, Inc. v. Fla. Dep't. of Envtl. Prot., 130 S. Ct. 2592, 2606 (2010) (addressing whether there is a "common-law tradition" supporting application of the Takings Clause to judicial action).

${ }^{236}$ See N. Ins. Co. v. Chatham Cnty., 547 U.S. 189 (2006) (explaining that the history of admiralty suits is not as important to a sovereign immunity question involving an underlying admiralty case as the principles in the Court's sovereign immunity jurisprudence). 
Although not dispositive with respect to the precise role of traditionalism in the Court's understanding of these specific provisions, this information is useful for understanding the breadth of traditionalism's impact on constitutional law and, in particular, for noting that traditionalism plays a role-for better or worse-in a wide range of constitutional questions.

\section{Identity (Traditionalism and the Justices)}

Beyond its general prevalence within the Roberts Court's constitutional jurisprudence and its impact across constitutional provisions, the use of traditionalism by individual members of the Court offers some additional insights and opportunities for future study. A cumulative look at each Justice's use of traditionalism shows that Justices who are regarded as conservative in their political or jurisprudential ideology are generally more likely to invoke traditionalism than their more liberal colleagues. ${ }^{237}$ Perhaps not surprisingly, particularly in light of his much-discussed defense of traditionalism in Michael $\mathrm{H}$. v. Gerald D., ${ }^{238}$ Justice Scalia is responsible for the greatest number of majority or plurality opinions invoking traditionalism (twelve) on the Roberts Court. Chief Justice Roberts is second on the list with ten opinions. Justice Kennedy is third with six, followed by Justice Breyer with five, Justices Stevens and Alito with four, and Justices Souter and Ginsburg with three. Justices Thomas and Sotomayor round out the list with one opinion each. ${ }^{239}$ Justice Thomas' place at the bottom of the list is noteworthy because it highlights a potential consequence of omitting concurring and dissenting opinions from the dataset. Despite Justice Thomas' selfproclaimed interest in historical information as a source of constitutional meaning, ${ }^{240}$ his relatively infrequent role as the author of majority or plurality opinions in constitutional cases renders his contribution to the data virtually

\footnotetext{
${ }^{237}$ This observation is not intended to represent any statistically significant correlation. There are a wide variety of variables that could influence this data, such as the assignment and certiorari grant processes, as well as the total number of majority opinions authored by a particular Justice during the relevant time period. For purposes of this discussion, it is sufficient to say that data pertaining to individual Justices' use of traditionalism could have significant application in future studies pertaining to judicial ideology and constitutional interpretation, and that the current observations are not inconsistent with that idea.

${ }^{238} 490$ U.S. 110, 122 (1989) ("In an attempt to limit and guide interpretation of the Clause, we have insisted not merely that the interest denominated as a 'liberty' be 'fundamental' (a concept that, in isolation, is hard to objectify), but also that it be an interest traditionally protected by our society.”).

${ }^{239}$ See infra Figure 3.

${ }^{240}$ See, e.g., McDonald v. City of Chicago, 130 S. Ct. 3020, 3062 (2010) (Thomas, J., concurring) ("I believe the original meaning of the Fourteenth Amendment offers a superior alternative" to other interpretive approaches).
} 
nonexistent. $^{241}$ These numbers are also potentially influenced by assignment procedures and trends; Justices who more often find themselves voting with the majority or who are perceived by the assignor as more likely to command a majority of votes are likely to draft a greater number of opinions overall and thus are more likely to draft a greater number of opinions invoking traditionalism, regardless of the relative commitment of that Justice to traditionalist reasoning. ${ }^{242}$ In an attempt to account for this phenomenon, the individual Justices' traditionalist opinions were also considered as a percentage of the total number of constitutional opinions drafted by each Justice during the same time period. ${ }^{243}$

This percentage data offers a view of the Justices' use of traditionalism that is remarkably similar to the cumulative data. ${ }^{244}$ As with the cumulative data, Justice Scalia and Chief Justice Roberts are the first two Justices on the percentage list. Justice Scalia authored the highest proportion of traditionalist opinions at $67 \%$ (twelve of eighteen), and Chief Justice Roberts employed traditionalism in $62.5 \%$ of his constitutional opinions. Justice Alito is the only member of the Court whose percentage ranking varies significantly from his cumulative results. Although four Justices wrote more traditionalist opinions than Justice Alito, he ranks third among his colleagues on the proportionality scale with precisely half of his constitutional opinions including positive indicators of traditionalism. This is interesting because it suggests that traditionalism may be a more important component of Justice

\footnotetext{
${ }^{241}$ According to the SCD, Justice Thomas authored four majority opinions in constitutional cases in the Court's first five terms. See The Supreme Court Database, supra note 95 (containing the version of the SCD dataset described as "Case-Centered Data" and "Cases Organized by Issue/Legal Provision").

${ }^{242}$ A Justice's use of traditionalism may also be driven by their need to persuade at least four of their colleagues to sign a majority opinion. Although this is admittedly a different rationale for employing traditionalism than a mere ideological preference for traditionalist reasoning, it is not necessarily different in kind, at least for purposes of this study. A Justice's willingness to employ a particular mode of constitutional analysis - even for reasons of garnering the assent of their colleagues - at minimum shows tacit acceptance of that analytical tool. It seems far more likely that the inclusion of a traditionalist argument in a constitutional case is due to the author's own analytical preference than to a bare desire to acquire votes. In reality, it may be that a combination of these two rationales is at work. Even in those instances, due to the reasons expressed above as well as the near impossibility of identifying when a Justice is expressing his or her true interpretive voice rather than trying to achieve broader acceptance of their opinion, the possibility of the latter cannot be grounds to exclude an opinion from the instant dataset.

${ }^{243}$ The total number of constitutional cases for each Justice during the tenure of the Roberts Court was obtained from the case-centered version of the SCD. See THE SuPREME COURT DATABASE, supra note 95 (containing the version of the SCD dataset described as "Case-Centered Data" and "Cases Organized by Issue/Legal Provision").

${ }^{244}$ See infra Figure 4.
} 
Alito's jurisprudence than the cumulative data indicates. Justice Alito is followed by Justices Kennedy and Breyer, whose cumulative scores (six and five, respectively) and percentage scores (43\% and $45 \%$, respectively) are nearly identical. The three lowest percentages belong to the three Justices who authored the fewest overall opinions implicating traditionalism. Justice Stevens' constitutional opinions included positive indicators of traditionalism one-third (33\%) of the time, while Justices Ginsburg and Thomas had the lowest total numbers of traditionalist opinions (three and one, respectively) as well as the lowest percentages of constitutional opinions invoking traditionalism $(27 \%$ and $25 \%$, respectively). ${ }^{245}$

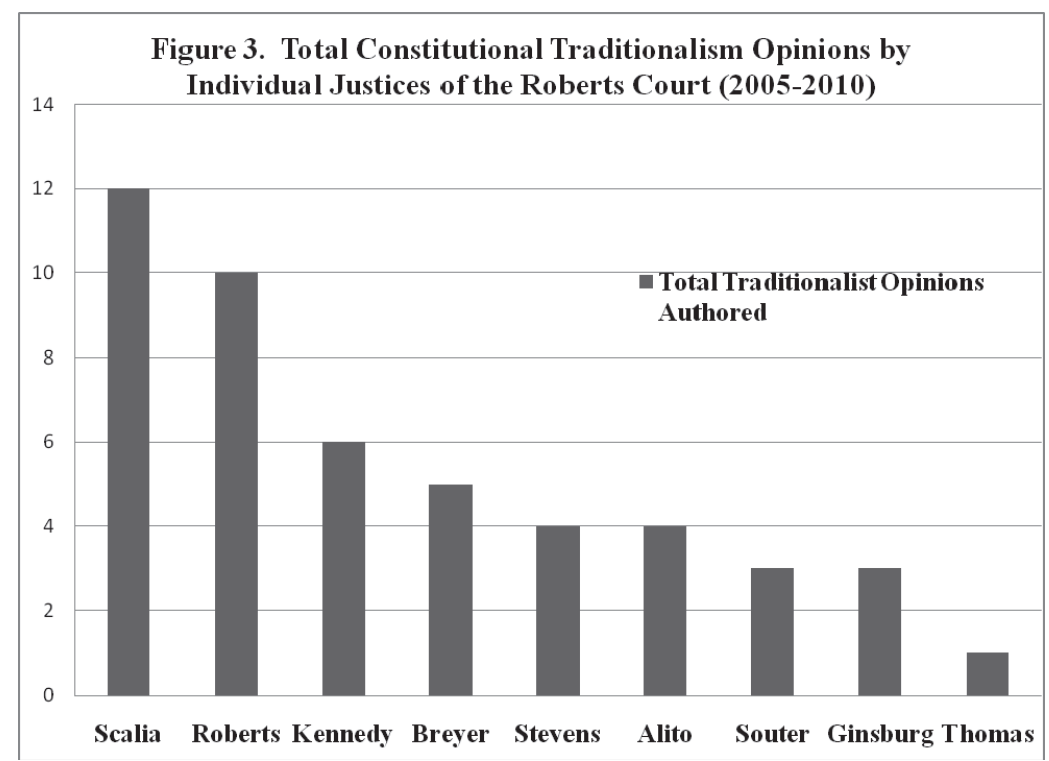

${ }^{245}$ See infra Figure 4. Similar data on Justice Sotomayor is not included in this portion of the analysis for two reasons: First, with only one constitutional opinion before the end of the 2009 term, the sample size is too small to say anything even suggestive of her approach to traditionalist interpretation. Second, the one opinion by Justice Sotomayor that included a positive indicator for traditionalism was not identified as a constitutional case by the SCD, thereby making it difficult to report as a percentage of her constitutional jurisprudence. 


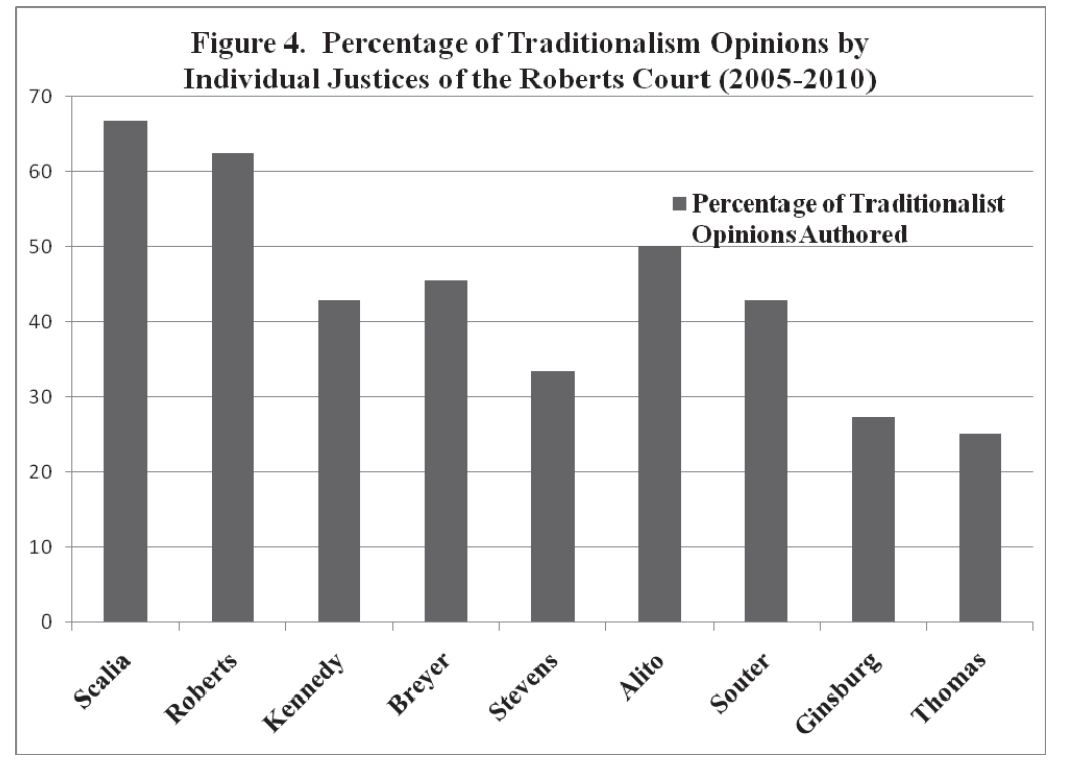

The similarities between the cumulative and percentage data at least suggest that the Justices near the top of both lists are more inclined to apply traditionalism in constitutional cases. The fact that the top two Justices on the cumulative listJustices Scalia and Roberts - and the top three Justices on the percentage listJustices Scalia, Roberts, and Alito-represent the most prolific conservative Justices on the Court tends to confirm the widely held view that traditionalism is more appealing to a politically and jurisprudentially conservative audience.

The story changes slightly when we consider not the opinions authored by a particular Justice, but the opinions to which an individual Justice lent his or her signature as a non-author. Justice Kennedy (31) has signed onto the greatest number of opinions containing positive indicators of traditionalism, followed by Chief Justice Roberts (28), and Justices Ginsburg (27), Thomas (26), Stevens (24), Souter (23), Breyer (24), Alito (24), and Scalia (20). ${ }^{246}$ While there admittedly may be myriad reasons for signing onto a particular opinion beyond whether tradition

\footnotetext{
${ }^{246}$ Justice O'Connor signed one opinion that contained a positive indicator for traditionalism during her time on the Roberts Court, but because she did not author any constitutional opinions during that time frame, let alone any constitutional opinions implicating traditionalist reasoning, her data is not particularly useful for these purposes. The same is true for Justice Sotomayor, who, due to her brief tenure on the Court, only authored one constitutional opinion and signed onto five opinions containing positive traditionalist indicators.
} 
was incorporated into the author's analysis, ${ }^{247}$ this data offers significant food for thought for future work. It provides a starting point for an inquiry into the relationship between a Justice's decision to join an opinion and his or her jurisprudential philosophy, as well as potential insight into which Justices employ a particular interpretive method - in this case, traditionalism - on its merits and which use interpretive methodologies to justify what is fundamentally a concern with case outcomes. Justices who join a higher number or proportion of traditionalist cases are less likely to do so in pursuit of some ideological outcome because it is less likely as the number of cases increases that the results of those cases will be ideologically consistent. By contrast, Justices who are more selective in signing onto opinions with positive traditionalist indicators may be less concerned with the purity of their interpretive approach and more focused on the results in particular cases.

Another interesting piece of information pertaining to individual Justices' advancement of traditionalism is the specific constitutional provision(s) each Justice was interpreting when he or she invoked the concept of tradition. Among the data in this area, two points of interest stick out. Approximately $80 \%$ of the Roberts Court cases containing positive indicators of traditionalism involved provisions pertaining to individual rights, as opposed to the structure or power of the federal government. ${ }^{248}$ Despite this 4:1 ratio of "rights" to "powers" cases, only Justices Scalia and Ginsburg employed traditionalism disproportionately in individual rights cases. All three of Justice Ginsburg's opinions containing positive indicators of traditionalism dealt with individual rights protections, and eleven of

${ }^{247}$ Especially in cases where they are not in danger of casting the deciding vote for a particular outcome, a Justice may sign another's opinion for anything from agreement with the result to support for the entire analysis, not to mention for reasons of collegiality and administrative efficiency that lie beyond the opinion's interpretive qualities altogether.

248 This number was arrived at by calculating the proportion of traditionalism cases interpreting amendments (forty-one) against the total number of constitutional cases decided by the Roberts Court using tradition in its first five terms (forty-nine). The distinction between constitutional articles and amendments is, of course, not a perfect proxy for issues of government structure and individual rights, but in this instance it is made more accurate by the fact that the Tenth Amendment, the one most likely to run afoul of the distinction because it deals primarily with government power rather than individual rights, was not interpreted in any of the cases containing positive indicators for traditionalism, and, as such, could not have distorted the accuracy of the calculated ratio. Similarly, the provisions relevant to this study that are contained in the constitutional articles are all directly related to government power; they do not include provisions such as the Article III guarantee of jury trials in criminal cases that implicate individual rights. See U.S. CONST. art. III, $\S 2$, cl. 3 . The only potential exception to this lies in cases dealing with the Suspension Clause, U.S. CONST. art. I, § 9, cl. 2, and because only one case in the dataset invoked tradition in interpreting the Suspension Clause, its impact on the calculated ratio is insignificant for purposes of the immediate discussion. 
the twelve constitutional provisions that Justice Scalia interpreted with reference to tradition were individual rights provisions. While it is not precisely clear what these data reveal, it is interesting by virtue of its being counter-intuitive. Traditionalism is widely characterized as a conservative doctrine that is resistant to change. $^{249}$ As a result, it has been and continues to be criticized for being inadequate to protect individual rights in a way consistent with current social attitudes and norms. ${ }^{250}$ It is thus a bit surprising that a liberally minded jurist like Justice Ginsburg would find the totality of her traditionalist leanings occurring in the individual rights context. It is easier to understand why a more conservative Justice like Justice Scalia would be interested in traditionalism's role in individual rights cases but more difficult to comprehend why a jurist with Justice Scalia's concern for judicial constraint would not apply this model to more cases addressing the scope of government power.

A second point of interest lies in the fact that Justice Scalia, despite being a champion of traditionalism in the substantive due process context, ${ }^{251}$ did not author any substantive due process opinions incorporating tradition during the first five years of the Roberts Court. ${ }^{252} \mathrm{He}$ instead invoked traditionalism in a total of six opinions that addressed two provisions of the Sixth Amendment-the right to confrontation and the right to counsel. He authored two more opinions with positive indicators for traditionalism in the Fourth Amendment context. Two-thirds of Justice Scalia's constitutional opinions employing traditionalism deal with issues of constitutional criminal procedure. Whatever factors may have contributed to Justice Scalia's disproportionate reference to tradition in criminal cases and his lack of any substantive due process opinions evoking tradition, this project serves to highlight this and other previously unavailable information in hopes of providing

${ }^{249}$ See, e.g., Adrian Vermeule, Common Law Constitutionalism and the Limits of Reason, 107 CoLuM. L. REV. 1482, 1487 (2007) ("Tradition can be and has been defended on a variety of instrumental grounds, including the value of small-scale incremental change as opposed to sudden large-scale change ....").

${ }^{250}$ See, e.g., Friedman \& Smith, supra note 27, at 10 (describing living constitutionalism as "the practice of interpreting the Constitution, usually in a non-historical way, to meet the needs of the present").

${ }^{251}$ See Michael H. v. Gerald D., 109 S. Ct. 2333, 2341 (1989) (“In an attempt to limit and guide interpretation of the Clause, we have insisted not merely that the interest denominated as a 'liberty' be 'fundamental' (a concept that, in isolation, is hard to objectify), but also that it be an interest traditionally protected by our society.”).

${ }^{252}$ In fact, according to the information available in the SCD, Justice Scalia has not authored any substantive due process opinions at all during Chief Justice Roberts' tenure. See THE SUPREME COURT DATABASE, supra note 95. 
some insight into the Justices' views on traditionalism in general, and on how traditionalism pertains to specific constitutional concepts and provisions. ${ }^{253}$

\section{Future CONSIDERATIONS}

This project has two primary goals. One is to provide the first comprehensive empirical account of the use of traditionalism in the Supreme Court's constitutional jurisprudence. The collected data represents an initial installment in this much larger endeavor, taking the recent fifth anniversary of the inception of the Roberts Court as an opportunity to define a subset of data that offers its own independent insight into a specific portion of the Court's history. The second is to employ the data presented here to identify and instigate future research projects that may not have been as easily addressed prior to the dataset's creation. It is the latter of these two goals that is the subject of this section.

There are at least two categories of future research that may develop from this data. The first is quantitative. The instant analysis stopped short of applying any quantitative methods to the new dataset. This is not, however, because there is no potential value to such an approach. In fact, much of the data included in the set was developed with future quantitative analysis in mind. In addition to the data associated with the preliminary findings discussed above, the dataset includes other variables that could be used to provide useful insight into important questions about traditionalist jurisprudence. Much empirical energy has been expended on the effects of political ideology on judging. This dataset includes information that allows that question to be explored in the specific context of traditionalism, such as the party affiliation of the nominating President for each Justice that authored an opinion incorporating traditionalism, as well as the political composition of the Senate that confirmed the Justice and the final tally of the Senate's confirmation vote.

Building on this idea, the dataset also facilitates empirical inquiry into whether traditionalism is more commonly a force for protecting civil rights or for legitimizing exercises of governmental authority. Data was collected as to whether the non-governmental party in each case that contained a positive indicator for traditionalism procured any relief as a result of the Supreme Court's decision. In

\footnotetext{
253 These preliminary findings with regard to the jurisprudence of the Roberts Court raise additional questions aimed at both a more detailed understanding of the Roberts Court itself and the development of its constitutional jurisprudence, as well as a broader understanding of how this information compares with similar information from other Courts. Although beyond the scope of this discussion, both of these questions are primary targets of the larger, ongoing empirical study of the use of traditionalism throughout the Supreme Court's history, mentioned supra note 6.
} 
U N I V E R S I T Y OF P I T T S B U R G H L A W R E V I E W

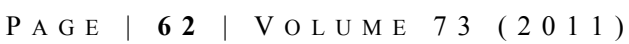

cases involving individual rights issues, this information allows for examination of traditionalism's potential to act as a bulwark against, or an affirmation of, government power. These cases can in turn be cross-referenced against the authoring Justice's nomination and confirmation data to address the relationship of traditionalism, political ideology, and civil rights.

There are other data points that could also inspire future research. For each opinion with a positive indicator for traditionalism, information was provided about the subject matter of, and the degree of public interest in, the case. This data permits future study of the power of traditionalism to influence particular areas of the law, as well as its usefulness in affecting social change or in addressing issues that generate heightened public attention or controversy. These variables can be combined with those relating to the constitutional provisions addressed by traditionalism, the specific Justices responsible for traditionalist analyses, the judicial ideology associated with those Justices, and the presence of individual rights cases implicating tradition to formulate a litany of more nuanced and robust quantitative investigations of the relationship of traditionalism to the constitutional jurisprudence of the Roberts Court and its members.

The second category of future work encouraged by the development of this dataset is qualitative. Information about the prominence of traditionalism in the Roberts Court and of the specific constitutional provisions and Justices involved in those analyses creates an important starting point for scholars interested in the robust and current normative debate surrounding traditionalist constitutional interpretation. ${ }^{254}$ While the data presented here offers the first wide-ranging factual account of how traditionalism appears in the Court's jurisprudence, it does not attempt to evaluate the quality of that reasoning or the normative features of its impact on constitutional law and society. Creating a framework for discussions about traditionalism gives future commentators the opportunity to consider traditionalism in a holistic way that was far more difficult - or perhaps even impossible - prior to this dataset's accounting of the scope of traditionalism's influence in specific doctrinal areas or in individual Justices' jurisprudence. The existence of data points beyond those discussed in the preliminary findings offered here also opens up opportunities for future qualitative or normative study. Questions about traditionalism and judicial politics or ideology, as well as issues of traditionalism's role in civil rights cases and in cases of greater public interest are all better and more easily addressed in normative as well as quantitative terms by

\footnotetext{
${ }^{254}$ See supra notes 59-75 and accompanying text (outlining the ongoing and high-profile current debate
} about constitutional traditionalism in academic literature). 
the presence of a factual baseline against which more detailed and sophisticated assumptions can be tested.

Finally, information about the Court's use of traditionalism opens up myriad possibilities for research into issues not specifically addressed by the database. For instance, what is the potential effect of the parties' briefing traditionalist arguments on the Court's use of traditionalism in its decisions? How is traditionalism used in concurring and dissenting opinions as opposed to majority or plurality decisions? Does traditionalism appear in conjunction with other interpretive approaches? If so, which ones? Is traditionalism frequently employed as a type of methodological compromise in cases with obvious interpretive disagreements between the Justices? Do non-textual constitutional principles such as federalism or separation of powers appear in cases employing traditionalism such that an independent inquiry into traditionalism's relevance to those principles is merited? These are just a sample of the seemingly infinite questions regarding constitutional traditionalism that are both worthy of scholarly attention and brought within closer reach by this project.

\section{Conclusion}

Despite its controversial status as a canon of constitutional interpretation, traditionalism appears as if it is here to stay as part of the Supreme Court's interpretive methodology. The goal of this project is not to engage in a normative debate over traditionalism's merits, but instead to shed light on its current role in Supreme Court decision-making. It is also not meant to be exhaustive. The baseline information made available here is designed to provide a springboard from which other more complex inquiries may emerge regarding the role of traditionalism in the Supreme Court's constitutional jurisprudence. Although there is much more to learn about traditionalism's place in the Court's past and future, there is strong evidence that five years into the Roberts Court's tenure, traditionalism has been used regularly, in many different contexts, and by many different Justices with different political and jurisprudential viewpoints. This evidence makes clear that any future study of the workings of this Court, its members, or the future direction of constitutional law in general must take traditionalism into account. 


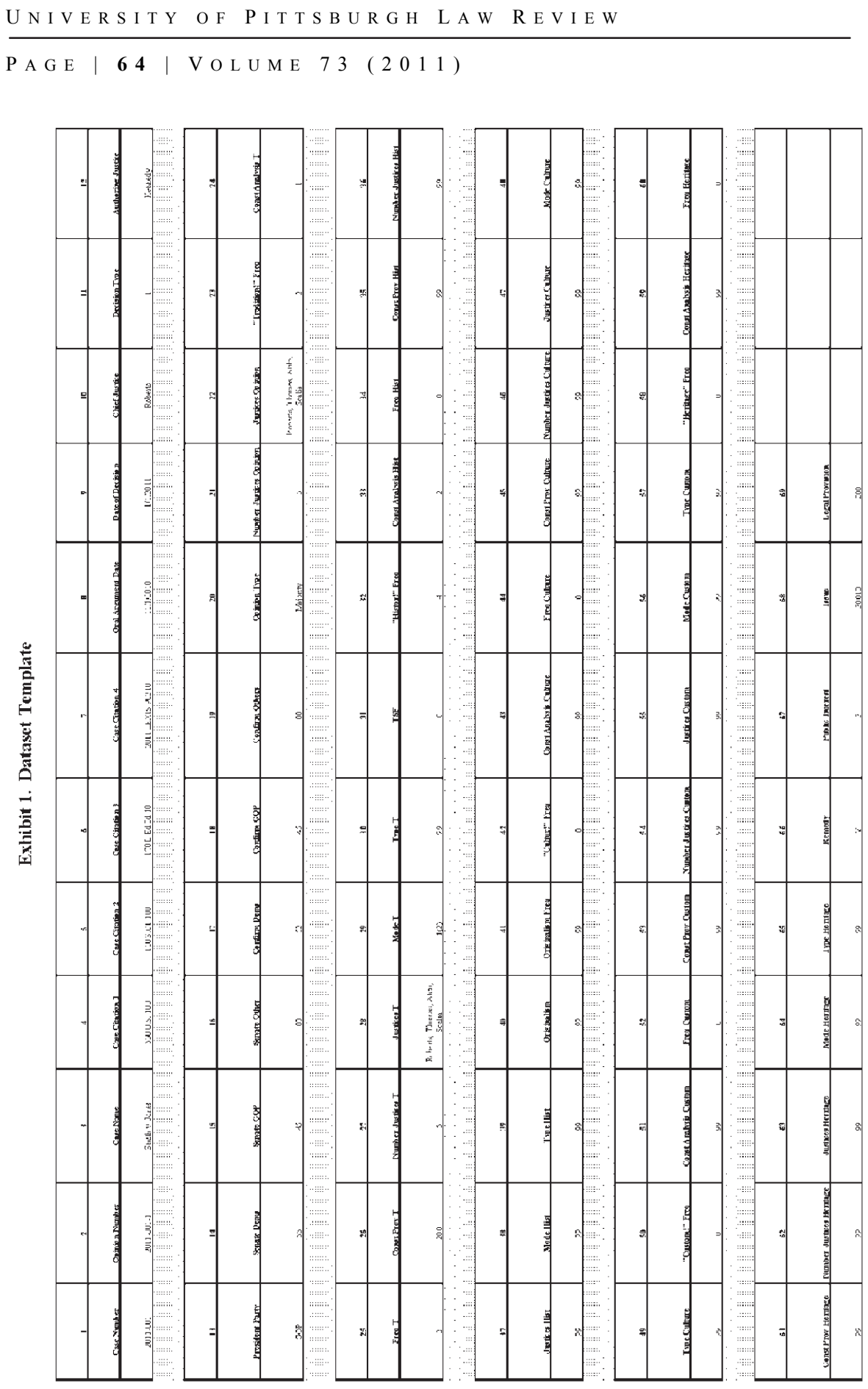

